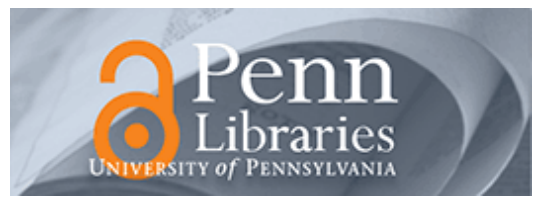

University of Pennsylvania

ScholarlyCommons

Management Papers

Wharton Faculty Research

$9-2001$

\title{
Uncertainty, Imitation, and Plant Location: Japanese Multinational Corporations, 1990-1996
}

Witold J. Henisz

University of Pennsylvania

Andrew Delios

Follow this and additional works at: https://repository.upenn.edu/mgmt_papers

Part of the Business Administration, Management, and Operations Commons, International Business Commons, and the Operations and Supply Chain Management Commons

\section{Recommended Citation}

Henisz, W. J., \& Delios, A. (2001). Uncertainty, Imitation, and Plant Location: Japanese Multinational Corporations, 1990-1996. Administrative Science Quarterly, 46 (3), 443-475. http://dx.doi.org/10.2307/ 3094871

This paper is posted at ScholarlyCommons. https://repository.upenn.edu/mgmt_papers/69

For more information, please contact repository@pobox.upenn.edu. 


\title{
Uncertainty, Imitation, and Plant Location: Japanese Multinational Corporations, 1990-1996
}

\author{
Abstract \\ In a study of a sample of 2,705 international plant location decisions by listed Japanese multinational \\ corporations across a possible set of 155 countries in the 1990-1996 period, we use neoinstitutional \\ theory and research on political institutions to explain organizational entry into new geographic markets. \\ We extend neoinstitutional theory's proposition that prior decisions and actions by other organizations \\ provide legitimization and information to a decision marked by uncertainty, showing that this effect holds \\ when the uncertainty comes from a firm's lack of experience in a market but not when the uncertainty \\ derives from the structure of a market's policymaking apparatus.

\section{Disciplines} \\ Business Administration, Management, and Operations | International Business | Operations and Supply \\ Chain Management
}




\title{
UNCERTAINTY, IMITATION AND PLANT LOCATION: JAPANESE MULTINATIONAL CORPORATIONS, 1990-96*
}

\author{
WITOLD J. HENISZ \\ Department of Management \\ The Wharton School \\ 2021 Steinberg Hall-Dietrich Hall \\ University of Pennsylvania \\ Philadelphia, PA 19104-6370 \\ Tel: (215) 898-0788 \\ Fax: (215) 898-0401 \\ E-mail: henisz@wharton.upenn.edu \\ and \\ ANDREW DELIOS \\ Department of Business Policy \\ National University of Singapore \\ FBA1, Level 2, \#02-29, 15 Law Link \\ Singapore 117591 \\ Tel: (65) 874-3094 \\ Fax: (65) 779-5059 \\ E-mail: fbaakd@nus.edu.sg
}

August 21, 2001

\footnotetext{
* This research was supported in part by an RGC Grant (\#HKUST6217/00H) and by a Social Sciences and Humanities Research Council of Canada Grant (\#410-2001-0143). We would like to thank Mauro Guillén, Michael Leiblein, Xavier Martin, Reed Nelson, Brian Silverman, Adrian Tschoegl, Joel Waldfogel, three anonymous referees and seminar participants at the University of Pennsylvania, the University of California at San Diego, the University of California at Berkeley and the Australian Graduate School of Management, for their comments as well as Connie Lun, Grace Chun Yu and Nick Wong for assistance in data collection and coding.
} 


\title{
UNCERTAINTY, IMITATION AND PLANT LOCATION: JAPANESE MULTINATIONAL CORPORATIONS, 1990-96*
}

\begin{abstract}
:
This paper combines neoinstitutional theory and research on political institutions to explain the process of organizational entry into new geographic markets. We extend neoinstitutional theory's proposition that prior decisions and actions by other organizations provide legitimization and information to a decision marked by uncertainty. We show this effect holds in the presence of uncertainty about market characteristics derived from a firm's lack of experience in a market, but not in the presence of policy uncertainty regarding the future shape of those market characteristics, where policy uncertainty derives from the structure of a market's policymaking apparatus. In investigating the sensitivity of frequency-based and trait-based imitation to firmspecific uncertainty, we examine the relative weight of social versus technical criteria across these imitative strategies. Our empirical tests also introduce a new time-varying measure of policy uncertainty in a country. This measure is derived from observable inter-temporal and cross-national differences in the structure of a country's political institutions. Our empirical setting is a sample of 2,705 international plant location decisions for the population of listed Japanese multinational corporations, across a possible set of 155 countries in the 1990-1996 period.
\end{abstract}


Researchers in the organizations literature have long noted the tendency of firms to avoid and reduce uncertainty (Cyert and March, 1963; Thompson, 1967). One prominent strategy for addressing uncertainty is imitative behavior that serves to either legitimate similar behavior (DiMaggio and Powell, 1983) or to provide informational cues that narrow the range of uncertainty (Levitt and March, 1988). Although recent empirical research has shown that uncertainty positively influences the adoption of different types of imitative behavior across a considerable range of market contexts, this research has typically explored imitation either within a relatively homogeneous set of firms (Haunschild, 1994; Podolny, 1994; Haunschild and Miner, 1997) or within a set of firms that operated in a narrowly-defined set of markets (Martin, Mitchell, and Swaminathan, 1995; Martin, Swaminathan, and Mitchell, 1998; Guillén, 2001).

Although this research has highlighted antecedents to imitation, including the idea that a firm's uncertainty about a market enhances imitation, it has not drawn a distinction between uncertainty derived from an organization's unfamiliarity with market characteristics and uncertainty derived from characteristics of the policymaking apparatus of a market that make the characteristics of a market unstable or difficult to forecast even for firms experienced in that market. We label these conditions firm-specific and policy uncertainty, respectively.

For market expansion decisions, such as recent organizational research on geographic expansion (Martin, et al., 1995; Martin, et al., 1998; Greve, 2000; Haveman and Nonnemaker, 2000; Guillén, 2001), the role of both of these types of uncertainty is paramount. Even so, we know little about how organizations with heterogeneous levels of firm-specific uncertainty about a market, will respond to market choices in which there is wide variation in policy uncertainty. We draw on a neoinstitutional perspective in a setting rich with variations in uncertainty across a large sample of organizations and markets to provide new insight into arguments concerning 
how these two types of uncertainty influence imitative market entry strategies, and the relative weighting of social and technical factors in those strategies.

The decision we examine is organizational growth in the form of the foundation of a new subsidiary company for the purpose of manufacturing in a country different from an organization's home country. The output of that subsidiary may be sold domestically and/or exported to the home country or third country markets. In either case, we term this an international plant location decision. This decision entails significant resource constraints and informational challenges (Haveman, 1993a) because of the limited scope for application of an organization's knowledge and its production and marketing capabilities acquired in its prior market activities to its new geographic markets (Aharoni, 1966).

By examining diversification across international political boundaries, our study highlights an important distinction between two types of uncertainty. First, we consider the impact of policy uncertainty induced by the structure of a nation's political institutions and the preferences of the actors that inhabit them. Political institutions that alter the costs of making new or altering old policies can have a substantial impact on the stability of those policies. In the presence of political institutions that induce policy uncertainty, a condition we define as political hazards, ex ante evaluation of the likely future investment conditions is prone to substantial error (North, 1990; Weingast, 1993; Henisz, 2000). Our measure of political hazards allows us to demonstrate the importance of "political change and political social structures, including the state in particular" (Carroll, Delacroix, and Goldstein, 1988) for market expansion, independent of firm-specific levels of uncertainty.

In addition to this market-specific measure of uncertainty, we also consider the influence of firm-specific uncertainty on international plant location decisions both directly and as it 
enhances the role of various imitative strategies. This consideration is important because traditional economic studies have emphasized the influences of country-level variation in market attractiveness and factor intensities (Markusen and Maskus, 1999:1) without explicit consideration of the social influences of other organizations (Martin, et al., 1998). This approach permits us to show how firms that vary in the level of uncertainty faced in the markets under consideration for investment vary in their reliance on different types of imitative strategies, such as frequency-based and trait-based imitation (Haunschild and Miner, 1997), or the seeking of analogues in their own prior experience as a guide to a prospective market entry decision (Kogut, 1983; Chang, 1995).

\section{BACKGROUND AND HYPOTHESES}

In growth by geographic diversification, an organization must successfully counter uncertainty surrounding the governance of transactions in new markets, to reap the desired benefits of higher profitability, growth or survival (Martin, et al., 1998). Research has shown that organizations can respond to uncertainty by removing transactions from the market, either by transforming exchange relationships into power relationships (Pfeffer and Salancik, 1978), or by embedding transactions in a hierarchy (Williamson, 1996). Even when making a hierarchical international plant location, however, an organization can still face considerable uncertainty about investment conditions in a host country (Root, 1968; Kobrin, Basek, Blank, and La Palombara, 1980).

Institutional theorists have emphasized that such uncertainty should increase the importance of social considerations relative to technical counterparts (Festinger, 1954; Meyer and Scott, 1983). One prominent social influence is the past behavior of actors in the immediate interorganizational environment. Past behavior conveys legitimacy to subsequent consistent behavior (Meyer and Rowan, 1977; DiMaggio and Powell, 1983; Hannan and Carroll, 1992). Alternately, as a large number of peer organizations engage in a decision, it becomes common 
knowledge, or a rule of thumb, to implement the same decision (Zucker, 1977; March, 1988). Relatedly, as an organization establishes a pattern of behaving in a certain manner, consistency with its own past behavior may either be perceived as internally legitimate or become a rule of thumb (Geertz, 1978; March, 1988). A contrasting perspective on the same phenomenon emphasizes the rational nature of the imitation process, in which firms look for market signals from their peers or from external capital markets that a given behavior is worth pursuing and thus generate rational bandwagons (Abrahamson and Rosenkopf, 1993).

Researchers emphasizing both social and technical considerations agree that imitation is more likely in the presence of uncertainty, but this research has not distinguished between the firm-specific uncertainty associated with a firm's level of experience in a market, and policy uncertainty that arises in a market due to uncertainty regarding the likely evolution of relevant government macroeconomic or regulatory policies. Research that has exploited country-level variation in studies of plant location decisions in the European Union has not included measures of firm-specific uncertainty that might induce firm-level variation in the location decision and the prevalence of imitative strategies (Mayer and Muchielli, 1998; Ford and Strange, 1999). In a different context, Podolny (1994), examined choices of issuing partners with a market-specific measure of uncertainty based on the grade of the bond offering but did not include a measure of an investment bank's familiarity with that grade of bond offering. Similarly, Haunschild (1994) used a sophisticated measure of uncertainty based on the lagged forecast errors of analysts for a takeover target, in her study of the determinants of acquisition premiums, but she likewise did not differentiate among firms with relatively more or less firm-specific information about a target. By contrast, researchers who included firm-specific differences in uncertainty in an international setting typically did not include consider cross-national variation in policy 
uncertainty (Hannan et al., 1995). This omission necessarily emerges in studies considering bilateral investments (Hennart and Park, 1994; Chang, 1995; Martin, et al., 1995; Martin, et al., 1998; Guillén, 2001).

\section{The Interorganizational Environment}

We begin our hypothesis development by establishing baseline expectations about the influence of interorganizational imitation on a firm's international plant location decisions. We consider two types of interorganizational imitation -- frequency-based and trait-based -- which are developed from the idea that organizations adopt different reference groups for imitation (Haunschild and Miner, 1997).

Frequency-based Imitation. Decisions based purely on the number of other firms that have adopted a given strategy are termed frequency-based imitation. Frequency-based imitation has been observed in organizational studies of market entry (Haveman, 1993a; Greve, 1996) and corporate governance (Fligstein, 1985; Palmer, Friedland, Hennings, and Powers, 1987) as well as political studies of the behavior of nations and U.S. states (Tolbert and Zucker, 1983; Kobrin, 1985; Strang, 1991).

Hypothesis 1a (H1a): The probability of locating a plant in a given country will be greater, the greater the number of prior plant locations by other firms.

Trait-based Imitation. A more selective process than frequency-based imitation is trait-based imitation in which the practices of subsets of the population enjoying high status or high similarity to a focal firm receive additional weight in the design of imitative strategies (Fombrun and Shanley, 1990; Haveman, 1993a; Strang and Tuma, 1993; Haveman and Rao, 1997). Studies of diversification have found that both the size and success of a firm enhance the sensitivity of its peers to its actions (Haunschild and Miner, 1997; Greve, 2000) as does its industrial context (Martin, et al., 1998; Guillén, 2001). 
Hypothesis 1b (H1b): The probability of locating a plant in a given country will be greater, the greater the number of prior plant locations by other firms in the same industry.

A firm also tends to imitate those organizations with which it is in social contact (Marsden and Friedkin, 1993). Like the organizational experience of high status firms or firms in the same industrial context, the experience of related firms can carry relatively greater weight in the decision calculus of a firm, than the experiences of all other firms. Close ties between firms lead to strong legitimization (DiMaggio and Powell, 1983) and facilitate the transfer of information and clues to member firms about new opportunities for investment and growth (Haunschild and Beckman, 1998). This form of mimetic behavior has been shown in populations of corporate boards contemplating adopting the M-form of governance (Fligstein, 1985; Palmer, Jennings, and Zhou, 1993), poison pills and golden parachutes (Davis, 1991; Davis and Greve, 1997), and takeover defenses and acquisitions (Haunschild, 1993; Haunschild, 1994), banks adoption of new technologies (Pennings and Harianto, 1992), hospitals considering a matrix organizational structure (Burns and Wholey, 1993), corporations adopting totalqualitymanagement practices (Westphal, Gulati, and Shortell, 1997), and innovation in biotechnology firms (Powell, Koput, and Smith-Doer, 1997).

Closely related to our empirical context are Martin et. al. (1995) and Martin et. al.'s (1998) studies of Japanese auto firms following their buyers, competitors and non-competing suppliers into the United States and Guillén's (2001) study of Korean firms entering the Chinese market. Like Guillén (2001), we focus on business group membership in which firms are tied to one another by cross-ownership, cross appointments of employees and by set forums for meeting and exchanging information. This form of association is not a buyer-supplier relationship, as in 
the vertical keiretsu studied in Martin et. al. (1995) and Martin et. al. (1998), instead it is a collection of firms that compete in many different industries or organizational fields.

Hypothesis 1c (H1c): The probability of locating a plant in a given country will be greater, the greater the number of prior plant locations by other firms in the same business group.

Each of these imitative strategies can be driven by social as well as technical considerations. Firms may be argued to gain legitimacy from imitating the most common behavior in a widely defined sample of firms and that egitimacy may be enhanced by the imitation of firms with whom the focal firm shares relevant characteristics or with whom the focal firm regularly interacts. Similarly, the number of firms adopting the same strategy or the similarity and/or strength of the information flow between a focal firm and the firms that it chooses to imitate may also influence rational bandwagons.

\section{Policy Uncertainty}

In contrast to the stimuli provided by the interorganizational environment that share technical and social considerations, we next turn to the purely technical role of policy uncertainty in the plant location decision. In general, and consistent with the idea that organizations avoid highly uncertain alternatives (Cyert and March, 1963), policy uncertainty deters investment, or entry into a market where policy uncertainty is high.

Where a firm is uncertain regarding future regulations, rates of taxation, or even macroeconomic policies, it is less likely to make long-term capital investments (Pindyck and Solimano, 1993). Among the many sources of policy uncertainty, political institutions that fail to constrain policymakers from altering the status quo regime are a prime candidate for influencing investor behavior. Where policymakers can act unilaterally or enjoy high certainty that a subservient or allied legislature and judicial branch will support their actions, future policies are likely to be more volatile in response to either exogenous shocks, changes in the identity of 
policymakers or even changes in the preferences of the existing policymakers. Such changes that are the result of direct lobbying by host country competitors or incumbents are of particular concern to foreign firms. We refer to countries that lack strong constraints on policy changes as politically hazardous.

Empirical work examining the history of private investment in telecommunications in five countries provides strong support for the hypothesis that long-lived and/or politically visible investments such as those in infrastructure sectors are particularly sensitive to the level of political hazards (Levy and Spiller, 1994). While the effects are likely strongest in the case of infrastructure, the proposition that these hazards are negatively associated with the incidence of foreign direct investment more broadly has also received support (Gastanaga, Nugent, and Pashamova, 1998; Wei, 2000).

Hypothesis 2 (H2): The probability of locating a plant in a given country will be greater the lower the level of political hazards of that country.

\section{Firm-Specific Uncertainty}

An important source of heterogeneity in a firm's propensity to locate a plant in a country is its prior investment experience in that specific country (Chang, 1995; Barkema, Bell, and Pennings, 1996). Firms new to a market are unlikely to have developed a heuristic for making an investment, or to have a system in place for determining and analyzing the relevant information. Inexperience thus heightens uncertainty about the market. One consequence of inexperience is that an organization begins to rely more heavily upon social cues to make decisions (DiMaggio and Powell, 1983; Haunschild and Miner, 1997). This can be transposed. Once a firm is experienced, it tends to look internally for solutions, and it places a greater reliance on technical decision-making criteria, instead of social criteria for investment. 
A firm's own experience facilitates foreign expansion because direct organizational experience yields substantive information regarding a country's culture, its common business practices, preferences of consumers, the process of policymaking, the preferences of key public and private actors and the likelihood of policy change (Barkema, et al., 1996; Delios and Henisz, 2000; Chang and Rosenzweig, 2001). In one way, host country experience should make a country more attractive for future investment because this experience is likely to provide an analogue on which future decisions can be based. Beyond this direct effect, which we control for but do not make the subject of a hypothesis due to our inability to discern this relationship from that of unobserved firm-specific heterogeneity, firms lacking experience in a prospective host country are also more likely to rely upon socially-based cues for plant location decisions because uncertainty strengthens the influence of social criteria (Festinger, 1954; DiMaggio and Powell, 1983).

Hypothesis 3a (H3a): The positive influence of the number of prior plant locations by other firms on the probability of plant location in a given country will be greater for firms inexperienced in that country, than for firms experienced in that country.

Hypothesis 3b (H3b): The positive influence of the number of prior plant locations by other firms in the same industry on the probability of plant location in a given country will be greater for firms inexperienced in that country, than for firms experienced in that country.

Hypothesis 3c (H3c): The positive influence of the number of prior plant locations by other firms in the same business group on the probability of plant location in a given country will be greater for firms inexperienced in that country, than for firms experienced in that country.

The richness of the international environment means a firm faces many countries as potential sites for its plant locations. It also means a firm could have made previous international expansions in countries other than the one under consideration. In addition to interorganizational 
mimetic strategies, previous international expansions can provide informational cues and rules of thumb on how to respond to conditions in another country.

The notion that an organization's previous experience can serve as a guide to a related decision is supported by research that shows organizations confine search to areas in which they are experienced, when faced with high uncertainty (March, 1988). Prior experience within an environment, or within an analogous situation delimits a reduced choice set, from which a firm makes its decision (Geertz, 1978). The benefits of accumulated past experience for making decisions under uncertainty have been found in samples of commercial banks (Pennings and Harianto, 1992), investment banks (Podolny, 1994) and acquiring firms (Haleblian and Finkelstein, 1999). Applying these ideas to the plant location decision, we expect to observe a positive correlation between a firm's plant location decisions and its probability of having encountered an empirical analogue in its past experience, which we assume to increase in the stock of that experience. Once again, however, we cannot separate the direct influence from that of unobserved firm-level heterogeneity, but we do expect that a firm will be less reliant upon its stock of experience in other countries when it has investment experience in a given country.

Hypothesis 3d (H3d): The positive influence of the prior international experience of a firm on the probability of plant location in a given country will be greater for firms inexperienced in that country, than for firms experienced in that country.

In contrast to the firm-specific uncertainty captured by firm-level experience in a potential host country, policy uncertainty derives from the structure of political institutions in a market, not from the level of a firm's knowledge and information about a market. It therefore differs substantively from an organization's uncertainty about a market in which uncertainty extends from a lack of knowledge or the absence of information in the organization about the environment (Tushman and Nadler, 1978). An organization's uncertainty about market 
conditions like consumer tastes, culture, factor prices and political conditions, can be reduced by the accumulation of organizational experience (Barkema, et al., 1996), but this accumulation of experience cannot change levels of uncertainty resultant from political institutional characteristics that make future policies less predictable.

The implication of this distinction between the two types of uncertainty is that there exists a form of environmental uncertainty that is unrelated to firm's level of knowledge about a market and unrelated to variance in outcomes by actors that implemented a particular decision (Haunschild and Miner, 1997). Consequently, firm-specific experience should not moderate the impact of policy uncertainty. Further, organizational strategies of imitation of any type, prevalent when a firm is uncertain about a market, should not be influenced by the extent of policy uncertainty in a market.

\section{METHODS}

\section{Setting}

To test our hypotheses, we use the setting of the international plant location decisions of Japanese manufacturing firms. Japan's manufacturing and trading firms began widespread exploration of overseas opportunities only in the 1970s. The early 1980s saw Japan achieve greater prominence as a source of world wide foreign investment. With the striking of the Plaza Accord in 1985 and the subsequent revaluation of the yen, foreign investment became a much more attractive option for Japan's firms, continuing a trend in which increasing strength in the yen led to greater foreign investment outflows from Japan. Japan's outward investment in both dollar flows and entry counts accelerated after 1985. At the time of the 1990 peak, Japan was the

second leading source of outward foreign direct investment (FDI) (United Nations, 1997). This peak also coincided with the height and burst of Japan's 'bubble economy'. 
The 1990-96 period that we examine begins in the aftermath of the collapse of Japan's equity market bubble. It continues through the subsequent recovery in foreign investment and ends prior to the beginning of the next downturn associated with the Asian financial crisis of 1997. In this time period, manufacturing foreign investment, the establishment of international plants, consistently accounted for 35-55 percent of outward investment in a given year. Joint ventures were the most prominently used entry mode, accounting for about 70 percent of the international plant locations made in the 1990-96 period (Toyo Keizai, 1999).

\section{Sample}

Our sample consisted of as many as 1,658 Japanese publicly listed parent firms whose primary line of business was in the manufacturing sector. Six hundred and fifty-eight of these firms made a total of 2,705 overseas investments in new manufacturing plants in 52 countries during the 1990-96 period. Our 1990s sample provides comprehensive data, rather than historical data on existing subsidiaries, which avoids a sample bias towards plants that survived. Second, this sample includes joint venture and wholly owned manufacturing plants because both modes are prominent features of Japanese foreign investment and comprehensive reviews of foreign investment identify that the market entry decision is often separate from the ownership decision (Dunning, 1993). Third, this sample avoids the inclusion of any speculative investments sparked by the late 1980s equity market bubble in Japan. This period also avoids data limitations on the range of host countries in our analysis which become more severe as we expand the sample period to include the 1980s or the 1970s.

We considered these advantages in striking a balance between incomplete investment histories, and the attrition of cases from missing data, with left censoring concerns for the plant location decisions of the firms in our sample. The result is that 77 percent of the investing firms in our sample had made an international investment prior to 1990, with 66 percent of 
international plant locations originating outside our study's sample period. The dataset does include the experience gained through these subsidiaries in its measures of firm-specific investment experience and prior plant locations by other firms, and the sample does have complete investment histories for each firm in the 1990-96 period. It includes annual time varying covariates on each parent firm and for the macroeconomic and political data in 155 potential host countries, including the level of political hazards.

\section{Data Sources}

We derived our parent company information from four sources. The first was the 1999 edition of the Nikkei NEEDS tapes. This source provided up to thirty-five years of annual data on Japanese listed firms' financial and accounting information. Using this source, we derived corporate data for the 1990 to 1996 period, for firm sales and employment, R\&D and advertising expenditures and export revenues. Where necessary, we supplemented the Nikkei NEEDS data by referring to the Japan Company Handbook, the Analyst's Guide, and annual reports. These sources provided financial and accounting data, qualitative data on Japanese firms (e.g., lines of business), and corporate demographic information (e.g., date of company founding). Our full sample comprised all listed firms in Japan in the study's time frame. ${ }^{1}$

To ascertain whether a parent firm located a plant in a given country in a given year, we examined the list of Japanese foreign subsidiaries found in six editions of Kaigai Shinshutsu Kigyou Souran-Kuni Betsu (Japanese Overseas Investments - by Country) (Toyo Keizai, 1999).

Toyo Keizai, Inc. compiled these data from information gathered in annual surveys of the

\footnotetext{
${ }^{1}$ Non-listed firms also participated in FDI, with 2,914 non-listed firms accounting for 30 percent of the FDIs undertaken in the time period of this study. Compared to listed firms, private firms were less active internationally on a per firm basis, holding a mean of 3.02 FDIs, compared to the mean of 13.72 for the listed firms that had at least one FDI. Subsidiaries established by private firms were, on average, 60 percent of the size of listed firms' foreign subsidiaries, by an employment measure. We therefore conclude that while our results may not be generalizable to the population of private firms, these firms form a comparatively minor component of total Japanese foreign direct investment.
} 
overseas operations of listed and non-listed Japanese firms. We used the 1986, 1989, 1992, 1994, 1997 and 1999 editions to construct our longitudinal profile of foreign subsidiaries.

We inspected the depth of coverage of Japanese Overseas Investments by comparing it to other sources for publicly-listed firms, namely annual reports and industry and company reports published by such bodies as the Wright Research Center. We found all but 33 firms (about 1.5 percent) of Japanese public firms that had foreign subsidiaries were listed in Japanese Overseas Investments. Further, the 33 firms that were not listed had just 70 foreign subsidiaries, which was less than 0.5 percent of the foreign subsidiaries listed in Japanese Overseas Investments. Given the lack of public information for numbers and characteristics of private firms, we could not make similar comparisons for data coverage, inclusive of private firms.

Once we identified our sample, we joined the firm-level data with country-level data on the economic, political and demographic characteristics of 155 potential host county markets. Of the more than two hundred countries and territories in existence during our sample period, this sample of countries omits only small island nations and city-states. The 155 countries in our sample represented more than 99 percent of total world domestic product and population in the years of our study. Of the 2,705 manufacturing plant location decisions that we observed, only two were in the excluded countries (one each in Guam and Macao).

The complete coverage for our sample numbered 2,010,096 unique combinations of firmcountry-years. This number was the product of the 1,658 firms in our sample by 155 countries and by 7 years, less those firm- years in which a country did not exist (e.g., the Czech and Slovak Republics prior to 1993), and those country-years prior to the founding of a firm. Although we had complete coverage in our sample for the theoretical variables of interest among the population of publicly traded Japanese manufacturing firms and potential host countries, the 
depth of coverage for our control variables was less. We note, however, that in contrast to the 57.4 percent reduction in firm-country-years in our base specification from missing data, we lose just 87 (3.2 percent) of the 2,705 plant location decisions.

Table 1 provides summary statistics for the variables included in our econometric analysis for the full sample for which data on each variable was available, the estimating sample, and for the subsamples of the estimating equation in which a firm did and did not have prior experience in a prospective host country and for subsamples in which plant locations did and did not occur. For each variable, the percentage of cases for which a variable was available is provided in the leftmost column. Table 2 presents a correlation matrix for all variables.

Even though the primary estimating smple was broadly representative across many independent variables, it contained a notable bias towards countries that had comparatively low levels of political hazards and had received Japanese foreign investment. Hence, the mean of counts of prior entries by Japanese firms was higher in the estimating sample than in the full sample. This suggests that we may have underestimated the effects of interest as the full sample of countries included a greater percentage of countries with high levels of political hazards and otherwise inferior environments where we expected the effect of political hazards to be greater in magnitude.

\section{Modeling Procedure}

Let $\mathrm{H}_{\mathrm{xit}}$ equal the hazard rate (the probability of plant location) for firm $\mathrm{x}$ in country $\mathrm{i}$ at time $\mathrm{t}$. According to our hypotheses there exist a set of country- and firm-level independent variables ( $\mathbf{w}_{\mathbf{x i t}}$ ) that determine $\mathrm{H}_{\mathrm{xit}}$.

$$
\mathrm{H}_{\mathrm{xit}}=\mathbf{b w}_{\mathrm{xit}}+\varepsilon_{\mathrm{xit}}
$$

So as to insure that $\mathrm{H}_{\mathrm{xit}}$ is bounded by 0 and 1 in the empirical results, we employed a logistic transformation $\left(\log \left(\mathrm{H}_{\mathrm{xit}} / 1-\mathrm{H}_{\mathrm{xit}}\right)\right)$. The coefficient estimates of $\mathbf{b}$ provide the change in 
the log-odds for each one-unit increase in the independent variables. We allow the base hazard rate (the intercept) to vary across each possible combination of year, industry and region by employing fixed effects in our specification. In the discrete time logit specification (Allison, 1984), we created a separate observation record for each unit of time that a firm was exposed to the hazard of potential plant location. Both the dependent and independent variables are time varying and the latter include both country-level and firm-level variance. We estimated the sample, with multiple observations across time for the same firm-country pair, using a maximum likelihood estimator for the traditional logit specification. This technique addresses problems of right-censoring and time- varying explanatory variables.

\section{Dependent Variables}

The strategic decision by firm $\mathrm{x}$ regarding a plant location in country $\mathrm{i}$ in period $\mathrm{t}$ was captured by the dummy variable

$E_{x i t}=1$ if firm $x$ locates a manufacturing plant in country $i$ at time $t, 0$ otherwise

There were 2,123 firm-country-years in which a plant location occurred. Among these, 422 included multiple entries by the same firm into the same country in the same year.

\section{Independent Variables}

Prior Plant Locations by Other Firms. We calculated the log of the count of prior plant locations by all the Japanese firms in our sample into a given country in each year. Note that here and in subsequent counts of entry or experience a plant location in 1990 would not appear in our data until 1991 and that years of operational experience would receive a diminishing weight as they recede into the past (Argote, Beckman, and Epple, 1990; Darr, Argote, and Epple, 1995; Ingram and Baum, 1997). Seventy-six per cent of observations in our primary estimating sample included a prior plant location of this type. To determine this count, we included all prior plant locations on which we had data including pre-1990 entrants. This sample includes subsidiaries 
that exited; however, due to limitations in our data source our record of exits does not include subsidiaries that were founded and exited before 1985, when Japanese outward investment was still at a relatively low level.

Prior Plant Locations by Firms in the Same Industry. We calculated the log of the count of prior plant locations into a given country by all Japanese firms in the same industry group prior to the establishment of a focal firm's foreign subsidiary. ${ }^{2}$ We used a Japanese analogue to the 2/3-digit SIC level, as categorized in the Nikkei NEEDS tapes. Forty-one per cent of observations included a prior plant location in the potential host country by a member of the same industry.

Prior Plant Locations by Firms in the Same Business Group. This measure was the log of the count of prior plant locations into a given country by all firms in the same business group (horizontal keiretsu). Horizontal keiretsu are business alliances in which member firms are integrated by such mechanisms as cross-appointments of directors and executives, crossshareholdings, and joint projects. Horizontal keiretsu therefore share certain characteristics with the interlocking board membership often studied in U.S. firms as a source of interorganizational imitation (Haunschild, 1993). In terms of technical considerations, the mechanisms linking horizontal keiretsu members foster good information flows between companies (Gerlach, 1992; Weinstein and Yafeh, 1995). Horizontal keiretsu have been called networks of knowledge (Imai, 1987), in which member firms gain information through ongoing trading relationships, personnel exchanges from one keiretsu company to another, and collaborative projects (Lincoln, Gerlach, and Ahmadjian, 1992; Weinstein and Yafeh, 1995). With these mechanisms, information about foreign markets, along with resources related to finance, technology or other fields, is also a

\footnotetext{
${ }^{2}$ Another referent group that might be adopted for imitation is the set of firms in the same global industry, but with a different national origin from that of a focal firm. Data limitations precluded such an examination in this study.
} 
pooled resource among member firms (Helou, 1991), which can be useful to reduce levels of uncertainty faced by an investing firm.

We did not include vertical keiretsu linkages in our tests, because the nature of business relationships is qualitatively different between horizontal and vertical keiretsu. Firms in a horizontal keiretsu are an association of businesses that compete in different organizational fields and may or may not have transactional relationships with one another. Firms in a vertical keiretsu exist in a distinct hierarchy of buyer-supplier relationships. These relationships are often exclusive, or the buyer-supplier relationships between vertical keiretsu members account for a majority of a member firm's transactions. Consequently, imitation in plant location decisions by vertical keiretsu members is likely to involve a motivation to replicate domestic business relationships in a new country, not the imitative behavior which is the focus of our hypothesis (Martin, et al., 1995; Martin, et al., 1998).

To identify whether a firm was a member in one of the six main horizontal keiretsu, we used the classification provided in Industrial Groupings in Japan (Dodwell, 1996/97). We used membership in the President's Council as the criterion to define membership. The closest and most tightly-allied members in a horizontal keiretsu were part of the President's Council. Hence, this definition of horizontal keiretsu affiliation was most likely to capture any information effect. Only 3.6 per cent of our observations included a prior plant location decision by a horizontal keiretsu member into the host country in question.

Prior International Experience. We based this measure on a firm's investment history internationally. We computed it as the log of the sum of subsidiary years of international (outside the prospective host country) experience. Just over sixty per cent of our observations included a prior international plant location by the potential investing firm. 
Policy Uncertainty. Our measure of political hazards, the political hazards index, was taken from (Henisz, 2000). It measured the extent to which a change in the preferences of any one actor may lead to a change in government policy. First, using existing political science databases, it identified the number of independent branches of government (executive, lower and upper legislative chambers, judiciary and sub-federal political institutions) with veto power over policy change. The preferences of each of these branches and the status quo policy were then assumed to be independently and identically drawn from a uniform, unidimensional policy space. This assumption allowed for deriving a quantitative measure of political hazards using a simple spatial model of political interaction.

This initial measure was then modified to take into account the extent of alignment across branches of government using panel data on the party composing the executive and legislative branches for each country. Such alignment increased the feasibility of policy change. The measure was then further modified to capture the extent of preference heterogeneity within each legislative branch that increased (decreased) the decision costs of overturning policy for legislatures aligned (opposed) to the executive.

The main results of the derivation (available in Henisz, 2000) are that (1) each additional veto point (a branch of government that is both constitutionally effective and controlled by a party different from other branches) provides a negative but diminishing effect on the total level of hazards and (2) homogeneity (heterogeneity) of party preferences within an opposed (aligned) branch of government is negatively correlated with the level of hazards. These results are consistent with the theoretical work of Tsebelis (2000) and Hammond and Butler (1996). Possible scores for the final measure of political hazards for a given country in a given year 
ranged from 0 (minimal hazards) to 1 (extremely hazardous). Appendix 1 provides more detail on the construction of this measure, including a sample derivation.

Firm-specific Uncertainty. We computed this measure as the log of the sum of subsidiary years of manufacturing experience in a prospective host country. Only 3.5 per cent of our observations included a prior plant location by the investing firm in the prospective host country. We also created an indicator variable equal to one when the measure of firm-specific experience in the prospective host country was non- zero. We used the coefficient estimates obtained by interacting this indicator variable with other independent variables to test hypotheses $3 \mathrm{a}-3 \mathrm{~d}$.

Country Controls. A country-level determinant of the attractiveness of a market-seeking foreign investment opportunity, and the probability of locating a plant in a given country, is the market potential of the host country (Grubaugh, 1987; Wheeler and Mody, 1992; Billington, 1999). Three measures, each computed annually for the 1990-96 period, captured market attractiveness. These were population $(\log )$, per capita GDP $(\log )$ and change in per capita GDP. The first two variables measured market size and the last proxied for market potential. We also included annual data on the average level of three tax rates for each nation - import (import tariff revenue divided by the value of imports) and export (export tariff revenue divided by the value of exports) trade taxes and taxes on capital - that were likely of interest to foreign investors. We included annual data on trade flow as a percentage of GDP to account for countries that for reasons other than the tariff rate were relatively open or closed to trade and thus relatively less or more attractive locations for production plants. Finally, we included the annual flow of FDI as a percentage of GDP as a counter to the argument that our measures of experience proxied for a welcoming investment climate otherwise missed by our controls. 
Controlling for factor-seeking investment, or those cases where the output of a subsidiary is almost entirely destined for export markets and the location choice is driven by production costs not market potential, is somewhat more difficult due to data limitations. In robustness checks we added measures that were proxies for the abundance of unskilled labor and the strength of a nation's infrastructure. We can also observe, however, that should the coefficient estimates on per capita income be negative that would suggest Japanese firms were, on average, drawn to a country not for its market potential but rather for lower factor costs of production.

Firm Controls. The capability to manage intangible assets has traditionally been assumed to provide a multinational firm with advantages in competition with host country firms that do not bear the transportation, communication and acclimation costs associated with managing a foreign subsidiary (Caves, 1971). We expected to observe that firms with higher levels of these assets, ceteris paribus, will have higher probabilities of plant location. We employed a five-year moving average of Research and Development (R\&D) intensity (R\&D expenditures as a percent of sales) and advertising intensity as proxies for the possession of intangible assets.

We accounted for firm size in our estimations because size itself can encompass other variables, such as the financial resources available to a firm, that might influence a firm's propensity to engage in foreign investments (Delacroix and Swaminathan, 1991). Furthermore, large firms may be involved in industries in which foreign production is typical (Dunning, 1993). Horst (1972), Owen (1982), and Li and Guisinger (1992) for US firms, and Kimura (1989) for Japanese firms, found a positive relationship between firm size and the propensity for foreign investment. We included annual data on firm sales to measure firm size, and note that the results are nearly identical when annual data on firm employment is used as a proxy for firm size. 
Holding the size of a firm constant, its age may also have an influence on the pattern of its multinational activity (Delacroix and Swaminathan, 1991), with young firms lacking the knowledge to expand overseas, and older firms having a status quo bias in operations (Guillén, 2001). To capture this non-linear effect, we included a quadratic term for age, with age measured as the years $(\log )$ since a firm's founding.

Finally, we controlled for the export intensity (exports to sales) of the parent firm to capture other unobserved differences in the international orientation of the firms in our sample. Like the intangible assets measure, we computed export intensity as a five-year moving average. Fixed Effects. We used region, year and industry indicator variables. The regional fixed effects proxy both for transportation costs, cultural differences and, to some extent, for differences in investment motivations. For example, Japanese investment in Europe is typically market-seeking while investment in Latin America or Asia is more likely to be factor-seeking. The regional indicator variables captured time invariant differences across Africa, Asia, Central \& Eastern Europe, Central America \& the Caribbean, former British colonies, the Middle East, South America and Western Europe. Annual fixed effects capture variation in exchange rates and global economic conditions. Industry fixed effects capture across-industry variation in the prevalence of foreign investment at the Japanese equivalent of a 2/3-digit SIC code.

\section{RESULTS}

Table 3 presents the results for the logistic discrete choice analysis described above incrementally adding the theoretical variables of interest. Model 1 presents coefficient estimates for the control variables. Model 2 adds the main effects for our theoretic variables of interest, with the exception of the host country experience indicator variable which is added in Model 3. Models 4 through 7 show individual interactions between the investment count or international 
experience measures and the host country experience indicator variable, with model 8 showing all host experience interactions entered simultaneously, and model 9 adding the interactions with political hazards. With the exceptions of models 4, 6 and 9, incremental chi-square statistics show an improvement in model fit compared to a model's respective baseline.

Referring to model 8, with the exception of age, age-squared, R\&D intensity and the ratio of trade to GDP, the coefficient estimates on the main effects were signed as expected (except per capita income and the profit and capital taxation ratio) and attained statistical significance with a $p$-value of 0.01 or less (except for the log of years of host country experience $\mathrm{p}=0.058$, the $\log$ of entries by firms in the same business group $\mathrm{p}=0.114$, advertising intensity $p=0.027$ and export intensity $p=0.011$ ). We discuss the support for our hypotheses in turn, using model 8 as the basis for this discussion.

\section{The Interorganizational Environment}

Frequency Based Imitation. The positive coefficient estimate on the prior plant location by all other firms variable and the resulting positive relationship between this measure of frequencybased imitation and the probability of plant location in panel 1 of Table 5 supports H1a. A firm follows patterns of previous investment observable to it among a broadly defined referent group of peers, here all Japanese firms. The economic effect of frequency-based imitation is modest. Holding all other variables constant at their mean levels, a firm with prior experience in a given country considering locating another plant in that country and observing that one standard deviation more than the mean level of other Japanese firms (2008) have previously entered, has a predicted probability of plant location 19 per cent higher than the predicted probability for the case where other firms had entered at the mean level (501 entries) (see Table 6).

Trait-based Imitation. The positive coefficient estimate on the count of prior entries by firms in the same industry and the same positive relationship in panel 2 of Table 5 supports H1b. Trait- 
based imitation, where traits are defined by industry membership, exerts a substantial effect on entry probabilities. Holding all other variables constant at their mean levels, the predicted probability of a plant location for a firm with prior experience in a country where its competitors have made one standard deviation more than the mean level of prior entries (57) is 46 percent higher than the predicted probability of a firm whose competitors have entered at the mean level (12 entries).

Although the keiretsu count variable has its expected sign $(\mathrm{p}<0.05)$, when only considered as a main effect, we find no support for H1c in the keiretsuthost experience interaction model (model 6), nor in the full interaction models reported as models 8 and 9.

\section{Policy Uncertainty}

The results provide strong support for Hypothesis 2 which predicted that increasing political hazards would decrease the probability of plant location in a prospective host country. The negative coefficient on political hazards reported in Column 3 of Table 3 and the same negative relationships observed in Table 5, regardless of the number of prior entries by all other firms (panel 1), the number of prior entries by other firms in a focal firm's industry (panel 2), a firm's level of investment experience in other countries (panel 3) or in a host-country (panel 4), demonstrate strong support for $\mathrm{H} 2$.

The magnitude of these effects is substantial. Holding experience constant, the reduction in the probability of plant location associated with an increase in political hazards from a level one standard deviation below the mean (e.g., Costa Rica, Ecuador, Hungary or Poland) to one standard deviation above the mean (e.g., Afghanistan, Algeria, Belarus, Burundi) ranges from 40 to 60 percent. These results are consistent with our hypothesis that uncertainty over future policy regimes acts as a substantial deterrent to the choice of a given country as a location for manufacturing plants. 


\section{Firm-Specific Uncertainty}

The relationship between the probability of locating a plant in a given country and (i) prior entries by all other firms (H3a), (ii) prior entries by other firms in the same industry (H3b), and (iii) a firm's stock of international experience (H3d) is larger for those countries in which firmspecific uncertainty is high; that is, when the focal firm has no country-specific experience. Support for these hypotheses is found by examining the coefficient estimate on the interaction between the indicator variable for focal firm experience in the prospective host country and the theoretical variable of interest. In each case, where the coefficient estimate is statistically significant, it is negative suggesting that the diminution of firm-specific uncertainty moderates the adoption of imitative strategies. As a result, the predicted probabilities of plant location in Table 5 are more sensitive to the behavior of various referent groups when firm-specific uncertainty is high as shown in the comparison between columns 1 and 2 of Table 6 . We did not find support for $\mathrm{H} 3 \mathrm{c}$ which posited that investing firm experience in the host country would moderate the impact of prior entries by firms in the same business group, while support for $\mathrm{H} 3 \mathrm{a}$ was attained with a p-value of 0.09 .

The economic magnitude of these predicted differences is striking as shown in Column 3 of Table 6. The predicted increase in the probability of entry based on an increase in entries by all other firms of one standard deviation from its mean is more than four times larger when firmspecific uncertainty is high (84 per cent as compared to 19 per cent). Turning to prior entries by other firms in the same industry, the increase in the predicted probability of entry resulting from a one standard deviation increase from the mean level is more modest, at 2.35 time larger, in going from a 46 per cent increase when firm-specific uncertainty is low to an increase of 107 per cent when firm-specific uncertainty is high. 
Hypothesis $3 \mathrm{~d}$ predicted that the impact of firm-specific experience in third countries would also be larger in the absence of firm-specific experience in a host country market. Here the predicted probability of entry with firm-specific experience in the host country increased by 18 per cent as an investing firm's experience in third countries increased by one standard deviation (181 subsidiary-years) from its mean level (70 subsidiary-years) compared to 150 per cent in the absence of such experience (an increase of 834 per cent). As a whole, these results suggest that where a firm lacks specific experience in a given country it faces more uncertainty about the business environment and relies more heavily on informational cues from its peers, its competitors and its own past experience.

While we can not hypothesize about a null result, we note that in contrast to the strong role observed for firm-specific uncertainty in increasing the prevalence of imitative strategies, only one of the coefficient estimates on the interactions between our measure of policy uncertainty (political hazards) and the measures of frequency- and trait-based imitation was statistically significant. As a whole, one fails to reject the null hypothesis that all of the coefficient estimates on this set of interaction terms are equal to zero ('delta' chi-square model 8 to 9 equals $4, \mathrm{p}>0.10)$.

\section{Control Variables}

The positive and significant coefficients on the population and per capita GDP growth terms show that firms were drawn to countries with larger market potential. Countries with lower per capita incomes, however, attracted more foreign investment suggesting the presence of factorseeking as well as market-seeking motivations. Low tax rates for imported goods and for exports were also important. A large inward flow of foreign direct investment similarly increased the predicted probability of plant location. The level of openness to trade was irrelevant for the plant location decision. 
Large firms were substantially more likely to locate a plant in a foreign country as were export intensive firms. The relatively weak results for the proxies for intangible assets (only advertising intensity attained statistical significance), while surprising, were not completely unexpected in the case of Japanese firms. As Belderbos and Sleuwaegen (1996) have shown, not all Japanese firms are motivated to undertake foreign investment in response to the possession of proprietary assets. Firms that do not possess such asset-based advantages often expand internationally to follow client/buyer firms, as industrial networks in Japan are replicated abroad by such investment. To further investigate this effect, it is necessary to distinguish between leading firms (those that expand internationally to extend proprietary advantages, e.g., Toyota), and follower firms that are part of the replicated network (e.g., Toyota's parts suppliers) (Martin, et al., 1995). Among the remaining variables, age was not a relevant effect for plant locations, while the regional, year and industry indicator variables were highly significant as a group and independently.

\section{SENSITIVITY TESTS}

An important question about our choice of specification involves the inclusion of firm-countryyears in which no investment occurred. On the one hand, these observations might be thought of as containing valuable information regarding the determinants of non-entry. On the other hand, their inclusion presents the risk of confounding the propensity to enter any foreign country with the determinants of entry into a specific country. The conditional logit specification (McFadden, 1974; Greene, 1997) addresses this concern and we present, in columns 10 and 11 of Table 4, qualitatively similar results obtained using that specification. Note that variables that vary only by firm (as opposed to across countries) are inestimable using this specification. We are therefore unable to test for support of $\mathrm{H} 3 \mathrm{~d}$ or to provide coefficient estimates for firm control variables. Further, the estimating sample is non-comparable as we are able to include only those 
firm-years in which an investment event occurred. Finally, the underlying assumption of the independence of irrelevant alternatives is likely violated in our context.

A random parameter logit specification, which is a more general form of the conditional logit, would address these limitations but it, unfortunately, relies on computationally demanding simulations that are infeasible given the scale of our dataset. Further, empirical evidence using the random parameter logit specification suggests that, in most instances, results do not vary appreciably from those obtained using a discrete time logit (Chung and Alcacer, 2000). With these qualifications in mind, the strong similarity in results across the columns provides confidence that the potential confound of entry rates and determinants of entry do not introduce any serious bias to our results. ${ }^{3}$

A second concern about our results revolved around the extent of independence of our observations across time. In particular, it seems likely that a decision by a firm not to locate a plant in a given country in one year is highly correlated with the same decision in a subsequent year. While, once again, the random parameter logit (Chung and Alcacer, 2000) would address this problem, it was computationally infeasible to implement. As we want to insure we were not biasing our standard errors downwards by incorporating repeated observations over time for a firm-country pair in our sample, we collapsed our sample into observations of the number of plant locations by a given firm in a given country over the $1990-96$ period. We took the mean scores for the independent variables except for the entry count and experience measures where we employed initial values to eliminate the problem of endogeneity caused by an entry in the early period of our sample increasing the count of "prior" entries of experience on the right hand side of the specification. Columns 12 and 13 in Table 4 rerun the specifications of columns 2 and

\footnotetext{
${ }^{3}$ We thank an anonymous referee for helping us to clarify this issue.
} 
8 in Table 3 using this cross-sectional dataset. We observed highly similar results in these specifications. We note, however, that interaction terms with a firm's host country experience tend towards insignificance because we lose variance in firm experience by the contraction of observations into a cross-sectional sample that fails to distinguish between single and multiple entries over the course of seven years.

To address this problem, columns 14 and 15 report runs of the same specification as columns 12 and 13 using a negative binomial estimation, not the poisson specification, because one can reject the null hypothesis of no overdispersion with a p-value of less than 0.001 . Now, firm-specific uncertainty significantly enhances the adoption of frequency-based but still not trait-based imitative strategies.

In light of the sensitivity of the support for $\mathrm{H} 3 \mathrm{c}$, another point of concern is the possibility that we are capturing an oligopolistic reaction effect rather than trait-based imitation. Similar hypotheses to our own derived from assuming oligopolistic or rivalrous behavior have been a subject of study in the field of international business (Knickerbocker, 1973; Graham, 1978; Hennart and Park, 1994; Anand and Kogut, 1997). To test the relative merits of this alternative interpretation, we calculated three sets of coefficient estimates that used the specification of Columns 8 and 9 of Table 3 on a sub-sample for which we had data, derived from the Fair Trade Commission of Japan, on the four-firm concentration ratio of the relevant manufacturing industry in Japan as well as subsamples of those firms operating in industries characterized by high and low concentration.

If oligopolistic reaction rather than imitation was operative, we would expect to observe that the coefficient estimates on the competitor experience variables were economically more significant for highly concentrated industries. While the results are somewhat stronger in highly 
concentrated industries, the difference is relatively small and most of our theoretical hypotheses retain support. Following (Caves, 1996), we also tested specifications that allowed the four-firm concentration ratio to enter nonlinearly (using both a linear and quadratic term) and again found no qualitative difference in the results. These results (available from the authors upon request) lend support to our interpretation that imitation, rather than strategic reaction, is an important influence on the probability of plant location.

Two additional concerns regarding our sample involve the data loss encountered when incorporating the country- and firm-level control variables and the potential omission of other relevant control variables. To address these concerns we reran the specification of Columns 8 and 9 of Table 3 using more and less inclusive sets of control variables respectively. We entered proxies for host country infrastructure (telecommunications lines per capita and line losses in electricity), the abundance of unskilled labor both entered independently (to capture the attractiveness for vertical multinational plant location decisions) and interacted with per capita GDP (to capture the lack of attractiveness for horizontal multinational plant location decisions) and the existence of a civil or foreign war. The results are qualitatively similar across the different specifications with the exception of the coefficient estimate on political hazards that substantially moderates in magnitude or even becomes statistically insignificant when countrylevel control variables are removed from the base specification (results available from authors upon request).

Finally, we also examined alternate interactions including using the log of firm-specific experience in the prospective host country and both the indicator variable and the logged experience variable. We were unable to improve upon the fit of the model using the simple indicator variable as an interaction term (results available from authors upon request). 


\section{DISCUSSION AND CONCLUSIONS}

This study investigated an important form of organizational diversification: international expansion into new geographic markets. We proposed that the interorganizational environment and policy uncertainty would directly influence a firm's international plant location decisions. We also examined the differential sensitivity of a firm to its interorganizational environment and its own prior international experience based upon its level of firm-specific uncertainty in a prospective market. As our evidence in support of these effects comes from an international context, and from a set of firms from a nation other than the United States, it provides substantial corroborating evidence for the concepts of imitation and mimetic isomorphism, and the relationship between these organizational strategies and an organization's level of uncertainty. More importantly, our study is the first of which we are aware to distinguish between the impact of firm-specific uncertainty and policy uncertainty on the adoption of various imitative strategies in the context of market expansion.

We first hypothesized that the number of other home country investments in a location would affect plant location decisions. This prediction was supported as entrants locating their first plant in a country were relatively more likely to imitate the past location decisions of other home country firms. Second, we hypothesized that the number of previous entries by organizations in the same industry or in the same business group would influence the probability of locating a plant in a given country. This prediction was supported for the influence of organizations in the same industry; however, the results for the influence of business group members were only weakly supported by the data.

Next, we hypothesized that the policy uncertainty in a potential host country would negatively influence the probability of plant location and here received strong and consistent support across types of empirical analyses and model specifications. Finally, our results also 
showed that organizations, when faced with firm-specific uncertainty, relied more heavily upon the past international expansion decisions of several referent groups of organizations as cues for their own behavior. In contrast, the influence of policy uncertainty on plant location decisions did not increase in the presence of firm-specific uncertainty nor did it influence the adoption of imitative strategies.

\section{Policy Uncertainty and Plant Location Decisions}

We used the setting of international expansion to highlight the influence that policy uncertainty, in the form of political hazards, had on the probability of plant location. In doing this, our results contribute to research on organizations by identifying the important impact that cross-sectional and intertemporal variation in the structure of a nation's political institutions had on geographic expansion. This influence occurs alongside the role of the interorganizational environment.

Although the political hazards measure was negatively related to the probability of plant location, the strength of this influence was no greater for firms with experience in a country than for firms without experience in a country. The insensitivity of the influence of political hazards to firm's level of experience in a host country shows that uncertainty inherent in the structure of a host country's political institutions could not be reduced by the accumulation of experience in a country. This result highlights a crucial difference between firm-specific uncertainty and policy uncertainty. Firm-specific uncertainty extends from a firm's lack of information about a market which managers may overcome by turning to social cues (DiMaggio and Powell, 1983; Haunschild, 1993; Podolny, 1994; Haunschild and Miner, 1997). Meanwhile, policy uncertainty is a technical construct that is a consequence of the political institutions in a market; hence, a firm cannot change the level of policy uncertainty in a market by acquiring information about a market. Consequently, strategies for dealing with policy uncertainty tend not to involve imitation. Instead a firm can use a srategy that directly mitigates political hazards, such as 
allying with local firms (Delios and Henisz, 2000) to increase conformity with the normative domain in a host country (Kostova and Zaheer, 1999). The more basic strategy we observed is to avoid investment in markets that have a high level of policy uncertainty. This latter strategy agrees with a basic premise of organizational search in which managers look to alternatives for which there is greater information, and avoid alternatives that are highly uncertain (Cyert and March, 1963).

\section{Imitation, Firm-specific Uncertainty and Plant Location Decisions}

This research contributes to a growing body of research in neoinstitutional theory that explores how social influences spark developments in an organization's strategy and actions. Mimetic, normative and coercive pressures lead organizations to uniformity in actions and structure (Fligstein, 1985; Haveman, 1993a). We extended prior related work that examined influences of prior entry decisions by members in vertical supply chains (Martin, et al., 1995; Martin, et al., 1998) by identifying and testing mimetic pressures emerging from two forms of interorganizational imitation, frequency-based and trait-based (Haunschild and Miner, 1997). We demonstrated these imitation modes were comparatively more prominent when firm-specific uncertainty about a market was high. We also allowed for the possibility that an organization could look internally, to its stock of prior experience, for cues about how to expand internationally, when faced with uncertainty.

Although results were generally supportive of the predictions for the influence modes, empirical evidence for trait-based imitation extending from the business group reference was not economically substantial nor was the prevalence of this imitative behavior influenced by firmspecific uncertainty. This result contrasts with prior research that has found prior entry by group

members to stimulate market entry (Kindleberger, 1983; Martin, et al., 1995; Belderbos and Sleuwaegen, 1996; Martin, et al., 1998; Guillén, 2001). In Guillén (2001), the expansions were 
observed in a confined, single-country setting, among 54 business groups. The business groups in Kindleberger (1983), Belderbos (1996), Martin et. al. (1995) and Martin et. al. (1998) were, however, vertically related groups in which uniformity in decisions might not be a case of mimetic isomorphism emerging from social pressures, but instead the extension of finance or buyer-supplier relationships to a new industrial context. Similar to our results, Chang (1995), Oliver (1988) and Mezias (1990), did not find evidence for imitation in analogous settings in which they explored the mimetic influence of interorganizational networks. On balance, there is weak evidence for an isomorphic effect emerging from interorganizational networks, such as that typified by business groups. The important caveat is that it may be necessary to define specific sub-groups within a business group, for example high status members or the most successful members, to test whether a mimetic isomorphic effect emerges from this sub-group.

\section{Social and Technical Considerations in Imitative Strategies}

As uncertainty should enhance the role of social criteria in plant location decisions, those imitative strategies that draw more heavily from social factors should be relatively more sensitive to the introduction of firm-specific uncertainty (DiMaggio and Powell, 1983; Haunschild, 1993; Podolny, 1994; Haunschild and Miner, 1997). We noted in Table 6 that differences in market entry propensities across firms with and without experience in a country for comparable changes in values of our measures of frequency and trait-based imitation were greater for the former than the latter. We interpret this result as evidence that while a social component to industry-based imitation does exist (firms gain more legitimacy by imitating firms in their own industry), a substantial portion of the observed imitation of such firms is based on technical rather than social criteria. In our sensitivity analysis, we explicitly examined the possibility that the imitation of industry counterparts was a competitive reaction rather than an imitative strategy and were able, subject to data limitations, to reduce concerns regarding this 
alternate explanation for these results. Taken together, these results suggest that a rational calculation is involved in this imitation, in which a firm gathers information from a competitor's decisions, and a firm infers best practices from the actions of a its competitors.

\section{Limitations and Future Research}

Research in organizational ecology has shown an interorganizational influence on market entry in its density dependence model of competition and legitimization (Hannan and Carroll, 1992). The density dependence model was developed in the context of organizational foundings, but it has been successfully extended to the case of organizational entry into new markets (Haveman, 1993a; Haveman, 1993b), while ecological models of density-dependent legitimization and competition have shown that these processes have cross-national linkages (Hannan, et al., 1995). Although we demonstrated that the neoinstitutional theory concepts of legitimization and imitation help explain international expansion decisions, we could not test an ecological perspective because that would require data on all domestic and international organizations in a country. Even though this would impose significant data challenges, research from economics has shown that foreign entrants alter competitive conditions and the behavior of domestic firms (Blomstrom, 1991; Chung, Mitchell, and Yeung, 1998), suggesting that organizational research could inform research on entry and exit rates in domestic industries exposed to competition from foreign firms.

Neoinstitutional research on market expansion strategy could benefit from exploring the influence of the regulative and normative domains, in addition to the cognitive domain which is this study's focus. Political hazards, as a part of the political environment, are a component of the regulative domain (Zukin and Dimaggio, 1990), which also comprises other features in the international context, such as capital controls, exchange rate regimes and labor market institutions (Van De Vliert and Yperen, 1996), that in turn can influence a firm's perceptions of 
the comparative levels of stability and uncertainty in a market. Just as for situations in which there is a high variance in outcomes from a strategic choice (Haunschild, 1994), but unlike for political hazards, a firm might be able to mitigate uncertainty that extends from these other features of the regulative domain by engaging in mimetic strategies.

Finally, our empirical results allow us to discuss the relative weight of social and technical considerations in various imitative strategies in the context of plant location decisions, but we did not examine other related decisions such as timing of entry or the mode of entry (Delios and Henisz, 2000; Chang and Rosenzweig, 2001) or partner selection, nor did we examine the performance implications of relying more heavily upon social or technical considerations in the plant location decision and these other related strategies. Subsequent research should compare the survival prospects or financial performance of firms that placed different weights on social and technical considerations in their geographic expansion strategies. Such an empirical study could also exploit differences in policy uncertainty, organizational structure, network structure and the "success" of geographic expansions.

\section{Conclusion}

Our results are among the first generated by large-scale archival data to demonstrate specific processes by which social influences affect corporate diversification decisions in an international setting. We distinguish between the impact of firm-specific and policy uncertainty on a firm's adoption of imitative strategies in geographic expansion. We highlight that, in contrast to firmspecific uncertainty, policy uncertainty is not a consequence of a firm's lack of knowledge about a market nor a consequence of high variability in the outcomes achieved by actors that engaged a particular decision (Haunschild and Miner, 1997). Instead, this uncertainty underlies a market itself. It inserts stochastic effects in a market that are difficult for a firm to mediate via the accumulation of experience or the imitation of referent groups. 
Our empirical results demonstrate that firm-specific uncertainty magnifies both frequency- and trait-based imitative strategies. They also suggest that while social criteria play a part in imitation, among various imitative strategies, industry-based imitation has a relatively larger technical component. Our analysis highlights the importance for researchers to further explore the complex relationships between social influences, entry, growth and performance in new markets, while explicitly considering the structure of the political institutions that support those markets. 
TABLE 1: Summary Statistics for Variables Included in Primary Specification

\begin{tabular}{|c|c|c|c|c|c|c|c|c|c|c|c|c|c|}
\hline \multirow[b]{2}{*}{ Variable } & \multirow[b]{2}{*}{ Coverage* } & \multicolumn{6}{|c|}{ Means } & \multicolumn{6}{|c|}{ Standard Deviation } \\
\hline & & All & $\begin{array}{r}\text { Primary } \\
\text { Estimating } \\
\text { Sample }\end{array}$ & $\begin{array}{l}\text { Without } \\
\text { Host- } \\
\text { Country } \\
\text { Exper. }\end{array}$ & $\begin{array}{l}\text { With } \\
\text { Host- } \\
\text { Country } \\
\text { Exper. }\end{array}$ & Dep $=0$ & Dep $=1$ & All & $\begin{array}{r}\text { Primary } \\
\text { Estimating } \\
\text { Sample }\end{array}$ & $\begin{array}{l}\text { Without } \\
\text { Host- } \\
\text { Country } \\
\text { Exper. }\end{array}$ & $\begin{array}{r}\text { With } \\
\text { Host- } \\
\text { Country } \\
\text { Exper. }\end{array}$ & Dep $=0$ & Dep $=1$ \\
\hline $\begin{array}{l}\text { Prior plant locations in host } \\
\text { country by other firms (Log) }\end{array}$ & $100.0 \%$ & 4.700 & 6.219 & 6.180 & 6.909 & 6.219 & 6.784 & 5.700 & 7.319 & 7.317 & 7.294 & 7.319 & 7.079 \\
\hline $\begin{array}{l}\text { Prior plant locations in host } \\
\text { country by industry }(\mathrm{Log})\end{array}$ & $100.0 \%$ & 0.593 & 0.949 & 0.851 & 3.664 & 0.943 & 3.706 & 1.209 & 1.440 & 1.342 & 1.374 & 1.434 & 1.370 \\
\hline $\begin{array}{l}\text { Prior plant locations in host } \\
\text { country by keiretsu (Log) }\end{array}$ & $100.0 \%$ & 0.047 & 0.083 & 0.059 & 0.751 & 0.081 & 0.956 & 0.366 & 0.496 & 0.386 & 1.567 & 0.487 & 1.820 \\
\hline $\begin{array}{l}\text { International experience of } \\
\text { investing firm }(\log )\end{array}$ & $100.0 \%$ & 1.917 & 2.292 & 2.193 & 4.997 & 2.286 & 4.727 & 2.153 & 2.166 & 2.126 & 1.344 & 2.164 & 1.723 \\
\hline $\begin{array}{l}\text { Host-country experience of } \\
\text { investing firm (Log) }\end{array}$ & $100.0 \%$ & 0.048 & 0.091 & 0.000 & 2.589 & 0.087 & 1.523 & 0.374 & 0.512 & 0.000 & 1.009 & 0.501 & 1.707 \\
\hline Political Hazards & $100.0 \%$ & 0.664 & 0.541 & 0.548 & 0.372 & 0.541 & 0.561 & 0.343 & 0.341 & 0.341 & 0.308 & 0.341 & 0.380 \\
\hline Firm Sales (Log) & $99.0 \%$ & 10.385 & 10.597 & 10.545 & 12.031 & 10.593 & 12.127 & 1.385 & 1.360 & 1.327 & 1.487 & 1.358 & 1.500 \\
\hline Firm Age & $98.8 \%$ & 49.531 & 51.561 & 51.445 & 54.661 & 51.552 & 55.542 & 17.144 & 16.248 & 16.225 & 16.570 & 16.245 & 17.140 \\
\hline $\begin{array}{l}\text { Real Per Capita Gross Domestic } \\
\text { Product (GDP) (Log) }\end{array}$ & $93.3 \%$ & 7.480 & 7.996 & 7.954 & 9.165 & 7.996 & 8.043 & 2.154 & 1.845 & 1.604 & 1.310 & 1.610 & 1.580 \\
\hline Population (Log) & $100.0 \%$ & 16.094 & 16.342 & 16.290 & 17.767 & 16.336 & 18.827 & 1.470 & 1.608 & 1.587 & 1.520 & 1.603 & 1.635 \\
\hline $\begin{array}{l}\text { Growth in Real Per Capita Gross } \\
\text { Domestic Product }\end{array}$ & $92.9 \%$ & 0.630 & 1.621 & 1.564 & 3.193 & 1.612 & 5.542 & 6.695 & 4.741 & 4.774 & 3.352 & 4.734 & $4.13 \mathrm{~T}$ \\
\hline $\begin{array}{l}\text { Research and Development } \\
\text { Intensity }\end{array}$ & $84.2 \%$ & 1.305 & 1.315 & 1.285 & 2.143 & 1.313 & 2.036 & 2.496 & 2.497 & 2.478 & 2.853 & 2.496 & 2.695 \\
\hline Advertising Intensity & $83.6 \%$ & 1.679 & 1.680 & 1.668 & 2.020 & 1.679 & 2.225 & 2.363 & 2.366 & 2.371 & 2.207 & 2.367 & 2.597 \\
\hline Export Intensity & $84.0 \%$ & 8.811 & 8.795 & 8.521 & 16.339 & 8.785 & 13.278 & 14.478 & 14.439 & 14.166 & 19.088 & 14.432 & 16.392 \\
\hline $\begin{array}{l}\text { Ratio of Foreign Direct } \\
\text { Investment to GDP }\end{array}$ & $95.5 \%$ & 1.738 & 1.927 & 1.909 & 2.418 & 1.924 & 3.056 & 3.524 & 3.634 & 3.661 & 2.806 & 3.637 & 2.615 \\
\hline Ratio of Trade to GDP & $94.1 \%$ & 75.100 & 72.663 & 72.371 & 80.686 & 72.677 & 66.896 & 48.243 & 47.573 & 45.751 & 82.934 & 47.536 & 60.907 \\
\hline $\begin{array}{l}\text { Import Taxes ( } \% \text { of value of } \\
\text { imports) }\end{array}$ & $54.7 \%$ & 9.502 & 9.012 & 9.203 & 3.749 & 9.021 & 5.024 & 10.305 & 9.905 & 9.149 & 5.190 & 9.100 & 4.960 \\
\hline $\begin{array}{l}\text { Export Taxes (\% of value of } \\
\text { exports) }\end{array}$ & $53.8 \%$ & 0.776 & 0.803 & 0.829 & 0.107 & 0.805 & 0.151 & 2.728 & 2.771 & 2.816 & 0.465 & 2.774 & 0.497 \\
\hline $\begin{array}{l}\text { Profit and capital Taxes ( } \% \text { of } \\
\text { GDP) }\end{array}$ & $58.0 \%$ & 6.902 & 6.367 & 6.286 & 8.577 & 6.367 & 6.391 & 7.631 & 4.443 & 4.432 & 4.162 & 4.443 & 4.341 \\
\hline
\end{tabular}

* As a percentage of all countries (firms) in the potential sample. 
TABLE 2: Correlation Matrix for Variables Included in Primary Specification

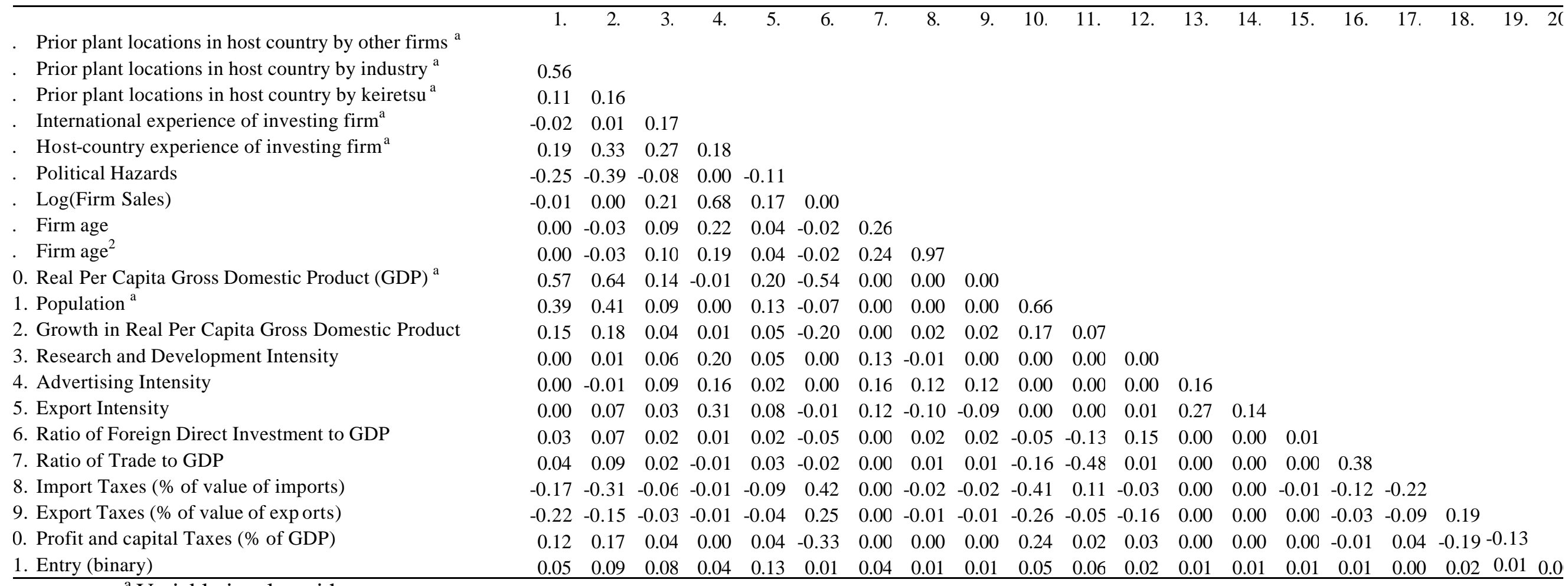

${ }^{a}$ Variable is a logarithm 
TABLE 3: Empirical Results a,b

\begin{tabular}{|c|c|c|c|c|c|c|c|c|c|}
\hline Variable & $\begin{array}{c}(1) \\
\text { CS-TS }\end{array}$ & $\begin{array}{c}(2) \\
\text { CS-TS }\end{array}$ & $\begin{array}{c}(3) \\
\text { CS-TS }\end{array}$ & $\begin{array}{c}(4) \\
\text { CS-TS }\end{array}$ & $\begin{array}{c}(5) \\
\text { CS-TS }\end{array}$ & $\begin{array}{c}(6) \\
\text { CS-TS }\end{array}$ & $\begin{array}{c}(7) \\
\text { CS-TS }\end{array}$ & $\begin{array}{c}(8) \\
\text { CS-TS }\end{array}$ & $\begin{array}{c}(9) \\
\text { CS-TS }\end{array}$ \\
\hline $\begin{array}{l}\text { Estimating } \\
\text { Technique }\end{array}$ & \begin{tabular}{|l} 
Discrete \\
Time \\
Logit
\end{tabular} & $\begin{array}{c}\text { Discrete } \\
\text { Time } \\
\text { Logit }\end{array}$ & $\begin{array}{l}\text { Discrete } \\
\text { Time } \\
\text { Logit }\end{array}$ & $\begin{array}{l}\text { Discrete } \\
\text { Time } \\
\text { Logit }\end{array}$ & $\begin{array}{l}\text { Discrete } \\
\text { Time } \\
\text { Logit }\end{array}$ & $\begin{array}{l}\text { Discrete } \\
\text { Time } \\
\text { Logit }\end{array}$ & $\begin{array}{l}\text { Discrete } \\
\text { Time } \\
\text { Logit }\end{array}$ & $\begin{array}{l}\text { Discrete } \\
\text { Time } \\
\text { Logit }\end{array}$ & $\begin{array}{l}\text { Discrete } \\
\text { Time } \\
\text { Logit }\end{array}$ \\
\hline Prior plant locations in host & & 0.230 & 0.217 & 0.229 & 0.208 & 0.217 & 0.224 & 0.236 & 0.234 \\
\hline country by other firms $(\ln )$ & & 0.000 & 0.000 & 0.000 & 0.000 & 0.000 & 0.000 & 0.000 & 0.001 \\
\hline Prior plant locations in host & & 0.620 & 0.608 & 0.605 & 0.640 & 0.608 & 0.598 & 0.623 & 0.618 \\
\hline country by industry (ln) & & 0.000 & 0.000 & 0.000 & 0.000 & 0.000 & 0.000 & 0.000 & 0.000 \\
\hline Prior plant locations in host & & 0.033 & 0.034 & 0.035 & 0.034 & 0.036 & 0.034 & 0.008 & 0.061 \\
\hline country by keiretsu (ln) & & 0.034 & 0.032 & 0.028 & 0.030 & 0.201 & 0.029 & 0.772 & 0.114 \\
\hline International experience of & & 0.406 & 0.395 & 0.397 & 0.396 & 0.395 & 0.421 & 0.432 & 0.405 \\
\hline investing firm (ln years) & & 0.000 & 0.000 & 0.000 & 0.000 & 0.000 & 0.000 & 0.000 & 0.000 \\
\hline Political Hazards & & $\begin{array}{l}-1.145 \\
0.000\end{array}$ & $\begin{array}{r}-1.142 \\
0.000\end{array}$ & $\begin{array}{r}-1.141 \\
0.000\end{array}$ & $\begin{array}{l}-1.139 \\
0.000\end{array}$ & $\begin{array}{l}-1.142 \\
0.000\end{array}$ & $\begin{array}{l}-1.138 \\
0.000\end{array}$ & $\begin{array}{l}-1.163 \\
0.000\end{array}$ & $\begin{array}{l}-1.303 \\
0.006\end{array}$ \\
\hline Host-country experience of & & & 0.650 & 1.103 & 0.971 & 0.652 & 1.564 & 2.504 & 2.489 \\
\hline investing firm $(0 / 1)$ & & & 0.000 & 0.000 & 0.000 & 0.000 & 0.000 & 0.000 & 0.000 \\
\hline Host-country experience of & & & & -0.062 & & & & -0.088 & -0.090 \\
\hline $\begin{array}{l}\text { investing firm }(0 / 1) \mathrm{X} \\
\text { Prior plant locations in host } \\
\text { country by other firms }(\ln )\end{array}$ & & & & & & & & 0.093 & 0.087 \\
\hline $\begin{array}{l}\text { Host-country experience of } \\
\text { investing firm }(0 / 1) \mathrm{X}\end{array}$ & & & & & $\begin{array}{l}-0.096 \\
0.016\end{array}$ & & & $\begin{array}{l}-0.096 \\
0.041\end{array}$ & $\begin{array}{l}-0.096 \\
0.045\end{array}$ \\
\hline $\begin{array}{l}\text { Prior plant locations in host } \\
\text { country by industry }(\ln )\end{array}$ & & & & & & & & & \\
\hline Host-country experience of & & & & & & -0.003 & & 0.037 & 0.017 \\
\hline $\begin{array}{l}\text { investing firm }(0 / 1) \mathrm{X} \\
\text { Prior plant locations in host } \\
\text { country by keiretsu (ln) }\end{array}$ & & & & & & 0.918 & & 0.250 & 0.609 \\
\hline $\begin{array}{l}\text { Host-country experience of } \\
\text { investing firm }(0 / 1) \mathrm{X}\end{array}$ & & & & & & & $\begin{array}{l}-0.234 \\
0.000\end{array}$ & $\begin{array}{l}-0.276 \\
0.000\end{array}$ & $\begin{array}{r}-0.271 \\
0.000\end{array}$ \\
\hline $\begin{array}{l}\text { International experience of } \\
\text { investing firm (ln years) }\end{array}$ & & & & & & & & & \\
\hline $\begin{array}{l}\text { Host-country experience of } \\
\text { investing firm }(0 / 1) \mathrm{X}\end{array}$ & & & & & & & & & $\begin{array}{l}0.103 \\
0.687\end{array}$ \\
\hline Political Hazards & & & & & & & & & \\
\hline Political Hazards X & & & & & & & & & 0.001 \\
\hline $\begin{array}{l}\text { Prior plant locations in host } \\
\text { country by other firms (ln) }\end{array}$ & & & & & & & & & 0.986 \\
\hline Political Hazards X & & & & & & & & & 0.005 \\
\hline $\begin{array}{l}\text { Prior plant locations in host } \\
\text { country by industry (ln) }\end{array}$ & & & & & & & & & 0.944 \\
\hline Political Hazards X & & & & & & & & & -0.081 \\
\hline $\begin{array}{l}\text { Prior plant locations in host } \\
\text { country by keiretsu (ln) }\end{array}$ & & & & & & & & & 0.044 \\
\hline Political Hazards X & & & & & & & & & 0.043 \\
\hline $\begin{array}{l}\text { International experience of } \\
\text { investing firm (ln years) }\end{array}$ & & & & & & & & & 0.337 \\
\hline Political Hazards X & & & & & & & & & -0.026 \\
\hline $\begin{array}{l}\text { Host-country experience of } \\
\text { investing firm (ln years) }\end{array}$ & & & & & & & & & 0.779 \\
\hline $\begin{array}{l}\text { Host-country experience of } \\
\text { investing firm (ln years) }\end{array}$ & & $\begin{array}{l}0.134 \\
0.000\end{array}$ & $\begin{array}{l}-0.036 \\
0.265\end{array}$ & -0.028 & -0.022 & -0.036 & 0.062 & 0.100 & 0.114 \\
\hline
\end{tabular}




\begin{tabular}{|c|c|c|c|c|c|c|c|c|c|}
\hline Firm Sales (ln) & $\begin{array}{l}0.718 \\
0.000\end{array}$ & $\begin{array}{l}0.241 \\
0.000\end{array}$ & $\begin{array}{l}0.251 \\
0.000\end{array}$ & $\begin{array}{l}0.246 \\
0.000\end{array}$ & $\begin{array}{l}0.248 \\
0.000\end{array}$ & $\begin{array}{l}0.251 \\
0.000\end{array}$ & $\begin{array}{l}0.292 \\
0.000\end{array}$ & $\begin{array}{l}0.293 \\
0.000\end{array}$ & $\begin{array}{l}0.294 \\
0.000\end{array}$ \\
\hline \multirow[t]{2}{*}{ Firm age } & 0.005 & -0.005 & -0.004 & -0.004 & -0.004 & -0.004 & -0.002 & -0.002 & -0.002 \\
\hline & 0.514 & 0.527 & 0.621 & 0.600 & 0.612 & 0.621 & 0.766 & 0.742 & 0.744 \\
\hline \multirow[t]{2}{*}{ Firm age $^{2}$} & 0.000 & 0.000 & 0.000 & 0.000 & 0.000 & 0.000 & 0.000 & 0.000 & 0.000 \\
\hline & 0.701 & 0.475 & 0.560 & 0.543 & 0.550 & 0.560 & 0.664 & 0.637 & 0.638 \\
\hline Real Per Capita Gross & 0.139 & -0.525 & -0.498 & -0.482 & -0.487 & -0.498 & -0.520 & -0.492 & -0.488 \\
\hline Domestic Produc & 0.029 & 0.000 & 0.000 & 0.000 & 0.000 & 0.000 & 0.000 & 0.000 & 0.000 \\
\hline \multirow[t]{2}{*}{ Population (ln) } & 0.851 & 0.372 & 0.380 & 0.382 & 0.385 & 0.379 & 0.373 & 0.382 & 0.381 \\
\hline & 0.000 & 0.000 & 0.000 & 0.000 & 0.000 & 0.000 & 0.000 & 0.000 & 0.000 \\
\hline Growth is & 0.042 & 0.037 & 0.039 & 0.039 & 0.039 & 0.039 & 0.039 & 0.039 & 0.039 \\
\hline Gros & 0.000 & 0.001 & 0.001 & 001 & 0.001 & 0.001 & 0.001 & 0.001 & 0.001 \\
\hline Research and Development & 0.011 & 0.006 & 0.007 & 0.007 & 0.007 & 0.007 & 0.011 & 0.012 & 0.013 \\
\hline Inte & 0.354 & 0.594 & 0.573 & 0.566 & 0.535 & 0.569 & 0.343 & 0.306 & 0.289 \\
\hline \multirow[t]{2}{*}{ Advertising Intensity } & 0.033 & 0.030 & 0.029 & 0.029 & 0.029 & 0.029 & 0.023 & 0.023 & 0.023 \\
\hline & 0.001 & 0.003 & 0.005 & 0.005 & 0.005 & 0.005 & 0.026 & 0.026 & 0.027 \\
\hline \multirow[t]{2}{*}{ Export Intensity } & 0.003 & -0.004 & -0.005 & -0.005 & -0.005 & -0.005 & -0.005 & -0.004 & -0.004 \\
\hline & 0.077 & 0.014 & 0.008 & 0.009 & 0.010 & 0.008 & 0.009 & 0.012 & 0.011 \\
\hline & & & & & & & & & 0.140 \\
\hline Investment to GDP & 0.000 & 0.000 & 0.000 & 0.000 & 0.000 & 0.000 & 0.000 & 0.000 & 0.000 \\
\hline \multirow[t]{2}{*}{ Ratio of Trade to GDP } & 0.005 & 0.000 & 0.000 & 0.000 & 0.000 & 0.000 & 0.000 & 0.000 & 0.000 \\
\hline & 0.000 & 0.724 & 0.732 & 0.640 & 0.761 & 0.732 & 0.742 & 0.664 & 0.657 \\
\hline \multirow{2}{*}{$\begin{array}{l}\text { Import Taxes ( } \% \text { of value } \\
\text { of imports) }\end{array}$} & -0.063 & -0.062 & -0.061 & -0.061 & -0.061 & -0.061 & -0.062 & -0.062 & -0.062 \\
\hline & 0.000 & 0.000 & 0.000 & 0.000 & 0.000 & 0.000 & 0.000 & 0.000 & 0.000 \\
\hline \multirow{2}{*}{$\begin{array}{l}\text { Export Taxes (\% of value } \\
\text { of exports) }\end{array}$} & 0.133 & -0.297 & -0.293 & -0.290 & -0.287 & -0.293 & -0.294 & -0.283 & -0.285 \\
\hline & 0.000 & 0.000 & 0.000 & 0.000 & 0.000 & 0.000 & 0.000 & 0.000 & 0.000 \\
\hline \multirow{2}{*}{$\begin{array}{l}\text { Profit and capital Taxes (\% } \\
\text { of GDP) }\end{array}$} & 0.043 & 0.028 & 0.030 & 0.028 & 0.028 & 0.030 & 0.031 & 0.026 & 0.027 \\
\hline & & & & & 0.010 & & 0.003 & 0.015 & 0.014 \\
\hline \multirow[t]{2}{*}{ Constant } & -38.208 & -22.656 & -23.055 & -23.185 & -23.199 & -23.050 & -23.432 & -23.862 & -23.821 \\
\hline & 0.000 & 0.000 & 0.000 & 0.000 & 0.000 & 0.000 & 0.000 & 0.000 & 0.000 \\
\hline Log Likeli & -9237 & -8549 & -8526 & -8525 & -8523 & -8526 & -8506 & -8498 & -8496 \\
\hline Number of Observations & 857,210 & 857,210 & 857,210 & 857,210 & 857,210 & 857,210 & 857,210 & 857,210 & 857,210 \\
\hline
\end{tabular}

${ }^{a}$ Coefficient estimates for region, time and industry dummies not reported.

${ }^{\mathrm{b}} \mathrm{P}$-values reported in italics underneath coefficient estimates. 
TABLE 4: Sensitivity (Robustness) Tests (Alternative Specifications) ${ }^{\text {a,b }}$

\begin{tabular}{|c|c|c|c|c|c|c|}
\hline Variable & $\begin{array}{c}(10) \\
\text { CS-TS }\end{array}$ & $\begin{array}{c}(11) \\
\text { CS-TS }\end{array}$ & $\begin{array}{l}(12) \\
\mathrm{CS}\end{array}$ & $\begin{array}{l}(13) \\
\mathrm{CS}\end{array}$ & $\begin{array}{l}(14) \\
\mathrm{CS}\end{array}$ & $\begin{array}{l}(15) \\
\mathrm{CS} \\
\end{array}$ \\
\hline $\begin{array}{l}\text { Estimating } \\
\text { Technique }\end{array}$ & $\begin{array}{c}\text { Conditional } \\
\text { Logit }\end{array}$ & $\begin{array}{c}\text { Conditional } \\
\text { Logit }\end{array}$ & $\begin{array}{l}\text { Discrete } \\
\text { Time Logit }\end{array}$ & $\begin{array}{l}\text { Discrete } \\
\text { Time Logit }\end{array}$ & $\begin{array}{l}\text { Negative } \\
\text { Binomial }\end{array}$ & $\begin{array}{l}\text { Negative } \\
\text { Binomial }\end{array}$ \\
\hline \multirow{2}{*}{$\begin{array}{l}\text { Prior plant locations in host country by } \\
\text { other firms }(\ln )\end{array}$} & 0.455 & 0.552 & 0.219 & 0.235 & 0.236 & 0.257 \\
\hline & 0.000 & 0.000 & 0.000 & 0.000 & 0.000 & 0.000 \\
\hline \multirow{2}{*}{$\begin{array}{l}\text { Prior plant locations in host country by } \\
\text { industry (ln) }\end{array}$} & 0.386 & 0.367 & 0.697 & 0.696 & 0.599 & 0.666 \\
\hline & 0.000 & 0.000 & 0.000 & 0.000 & 0.000 & 0.000 \\
\hline \multirow{2}{*}{$\begin{array}{l}\text { Prior plant locations in host country by } \\
\text { keiretsu }(\ln )\end{array}$} & 0.031 & 0.006 & 0.055 & 0.047 & 0.029 & 0.026 \\
\hline & 0.500 & 0.929 & 0.018 & 0.142 & 0.100 & 0.345 \\
\hline \multirow{2}{*}{$\begin{array}{l}\text { International experience of investing } \\
\text { firm (ln years) }\end{array}$} & $\mathrm{n} / \mathrm{a}$ & $\mathrm{n} / \mathrm{a}$ & 0.526 & 0.537 & 0.461 & 0.503 \\
\hline & & & 0.000 & 0.000 & 0.000 & 0.000 \\
\hline \multirow[t]{2}{*}{ Political Hazards } & -0.931 & -0.837 & -2.099 & -2.141 & -1.689 & -1.932 \\
\hline & 0.000 & 0.000 & 0.000 & 0.000 & 0.000 & 0.000 \\
\hline \multirow{2}{*}{$\begin{array}{l}\text { Host-country experience of investing } \\
\text { firm }(0 / 1)\end{array}$} & & 3.117 & & 2.461 & & 2.653 \\
\hline & & 0.000 & & 0.000 & & 0.000 \\
\hline $\begin{array}{l}\text { Host-country experience of investing } \\
\text { firm }(0 / 1) \mathrm{X}\end{array}$ & & -0.169 & & -0.119 & & -0.162 \\
\hline \multicolumn{7}{|l|}{$\begin{array}{l}\text { Prior plant locations in host country by } \\
\text { other firms }(\ln )\end{array}$} \\
\hline \multirow{3}{*}{$\begin{array}{l}\text { Host-country experience of investing } \\
\text { firm }(0 / 1) \mathrm{X} \\
\text { Prior plant locations in host country by } \\
\text { industry }(\mathrm{ln})\end{array}$} & & -0.144 & & -0.086 & & -0.040 \\
\hline & & 0.014 & & -0.188 & & -0.485 \\
\hline & & & & & & \\
\hline \multirow{2}{*}{$\begin{array}{l}\text { Host-country experience of investing } \\
\text { firm }(0 / 1) X\end{array}$} & & 0.059 & & 0.019 & & 0.020 \\
\hline & & 0.114 & & 0.656 & & 0.565 \\
\hline \multicolumn{7}{|l|}{$\begin{array}{l}\text { Prior plant locations in host country by } \\
\text { keiretsu }(\ln )\end{array}$} \\
\hline \multirow{3}{*}{$\begin{array}{l}\text { Host-country experience of investing } \\
\text { firm }(0 / 1) \mathrm{X} \\
\text { International experience of investing } \\
\text { firm (ln years) }\end{array}$} & & -0.311 & & -0.371 & & -0.425 \\
\hline & & 0.000 & & 0.000 & & 0.000 \\
\hline & & & & & & \\
\hline \multirow{2}{*}{$\begin{array}{l}\text { Host-country experience of investing } \\
\text { firm (ln years) }\end{array}$} & 0.118 & 0.152 & 0.115 & 0.294 & 0.046 & 0.336 \\
\hline & 0.000 & 0.000 & 0.000 & 0.000 & 0.029 & 0.000 \\
\hline
\end{tabular}




\begin{tabular}{|c|c|c|c|c|c|c|}
\hline \multirow[t]{2}{*}{ Firm Sales $(\ln )$} & $\mathrm{n} / \mathrm{a}$ & $\mathrm{n} / \mathrm{a}$ & 0.219 & 0.264 & 0.110 & 0.268 \\
\hline & & & 0.000 & 0.000 & 0.000 & 0.000 \\
\hline \multirow[t]{2}{*}{ Firm age } & $\mathrm{n} / \mathrm{a}$ & $\mathrm{n} / \mathrm{a}$ & 0.007 & 0.008 & 0.007 & 0.014 \\
\hline & & & 0.406 & 0.355 & 0.322 & 0.096 \\
\hline \multirow[t]{2}{*}{ Firm age ${ }^{2}$} & $\mathrm{n} / \mathrm{a}$ & $\mathrm{n} / \mathrm{a}$ & -0.000 & -0.000 & -0.000 & -0.000 \\
\hline & & & 0.546 & 0.494 & 0.446 & 0.111 \\
\hline Real Per Capita Gross Domestic & -0.306 & -0.301 & -0.661 & -0.654 & -0.525 & -0.617 \\
\hline Product $(\ln )$ & 0.002 & 0.007 & 0.000 & 0.000 & 0.000 & 0.000 \\
\hline \multirow[t]{2}{*}{ Population (ln) } & 0.288 & 0.276 & 0.526 & 0.525 & 0.444 & 0.448 \\
\hline & 0.000 & 0.000 & 0.000 & 0.000 & 0.000 & 0.000 \\
\hline Growth in real per capita Gross & 0.000 & 0.000 & 0.055 & 0.057 & 0.019 & 0.040 \\
\hline Domestic Product & 0.207 & 0.000 & 0.046 & 0.040 & 0.439 & 0.106 \\
\hline \multirow[t]{2}{*}{ Research and Development Intensity } & $\mathrm{n} / \mathrm{a}$ & $\mathrm{n} / \mathrm{a}$ & 0.006 & 0.012 & -0.004 & 0.005 \\
\hline & & & 0.698 & 0.452 & 0.802 & 0.710 \\
\hline \multirow[t]{2}{*}{ Advertising Intensity } & $\mathrm{n} / \mathrm{a}$ & $\mathrm{n} / \mathrm{a}$ & 0.020 & 0.015 & 0.024 & 0.009 \\
\hline & & & 0.157 & 0.302 & 0.046 & 0.499 \\
\hline \multirow[t]{2}{*}{ Export Intensity } & $\mathrm{n} / \mathrm{a}$ & $\mathrm{n} / \mathrm{a}$ & -0.007 & -0.006 & -0.004 & -0.005 \\
\hline & & & 0.006 & 0.006 & 0.050 & 0.017 \\
\hline \multirow{4}{*}{$\begin{array}{l}\text { Ratio of Foreign Direct Investment to } \\
\text { GDP } \\
\text { Ratio of Trade to GDP }\end{array}$} & 0.143 & 0.139 & 0.196 & 0.205 & 0.163 & 0.200 \\
\hline & 0.000 & 0.000 & 0.000 & 0.000 & 0.000 & 0.000 \\
\hline & -0.004 & -0.004 & 0.002 & 0.002 & 0.002 & 0.001 \\
\hline & 0.001 & 0.001 & 0.277 & 0.374 & 0.220 & 0.697 \\
\hline \multirow[t]{2}{*}{ Import Taxes (\% of value of imports) } & -0.059 & -0.059 & -0.083 & -0.084 & -0.059 & -0.076 \\
\hline & 0.000 & 0.000 & 0.000 & 0.000 & 0.000 & 0.000 \\
\hline \multirow[t]{2}{*}{ Export Taxes (\% of value of exports) } & -0.312 & -0.300 & -0.840 & -0.859 & -0.711 & -0.795 \\
\hline & 0.000 & 0.000 & 0.000 & 0.000 & 0.000 & 0.000 \\
\hline \multirow[t]{2}{*}{ Profit and capital Taxes ( $\%$ of GDP) } & 0.021 & 0.014 & 0.086 & 0.083 & 0.089 & 0.078 \\
\hline & 0.042 & 0.201 & 0.000 & 0.000 & 0.000 & 0.000 \\
\hline \multirow[t]{2}{*}{ Constant } & $\mathrm{n} / \mathrm{a}$ & $\mathrm{n} / \mathrm{a}$ & -15.585 & -16.269 & -13.872 & -15.111 \\
\hline & & & 0.000 & 0.000 & 0.000 & 0.000 \\
\hline Log Likelihood & -4732 & -4690 & -4339 & -4322 & -4666 & -5746 \\
\hline Number of Observations & 144,639 & 144,639 & 142,723 & 142,723 & 142,723 & 142,723 \\
\hline
\end{tabular}

${ }^{a}$ Coefficient estimates for region, time and industry dummies not reported.

${ }^{\mathrm{b}} \mathrm{P}$-values reported in italics underneath coefficient estimates 
Table 5: Predicted Probability of Plant Location in a Prospective Host Country

\begin{tabular}{|c|c|c|c|c|c|c|c|}
\hline & & \multicolumn{3}{|c|}{$\begin{array}{c}\text { Without Firm-Specific } \\
\text { Experience (Firm-Specific } \\
\text { Uncertainty High) }\end{array}$} & \multicolumn{3}{|c|}{$\begin{array}{c}\text { With Firm-Specific Experience } \\
\text { (Firm-Specific Uncertainty } \\
\text { Low) }\end{array}$} \\
\hline & & $\begin{array}{l}\text { Political } \\
\text { Hazards } \\
\text { at mean } \\
\text { minus } \\
\text { one } \\
\text { standard } \\
\text { deviation }\end{array}$ & $\begin{array}{l}\text { Political } \\
\text { Hazards } \\
\text { at mean } \\
\text { level }\end{array}$ & $\begin{array}{l}\text { Political } \\
\text { Hazards } \\
\text { at mean } \\
\text { plus one } \\
\text { standard } \\
\text { deviation }\end{array}$ & $\begin{array}{l}\text { Political } \\
\text { Hazards } \\
\text { at mean } \\
\text { minus } \\
\text { one } \\
\text { standard } \\
\text { deviation }\end{array}$ & $\begin{array}{c}\text { Political } \\
\text { Hazards } \\
\text { at mean } \\
\text { level }\end{array}$ & $\begin{array}{l}\text { Political } \\
\text { Hazards } \\
\text { at mean } \\
\text { plus one } \\
\text { standard } \\
\text { deviation }\end{array}$ \\
\hline Number of Prior & 1 & $0.090 \%$ & $0.061 \%$ & $0.041 \%$ & $13.92 \%$ & $10.16 \%$ & $7.32 \%$ \\
\hline Entries by Other Firms & 10 & $0.155 \%$ & $0.104 \%$ & $0.070 \%$ & $18.53 \%$ & $13.72 \%$ & $10.00 \%$ \\
\hline into the prospective & 50 & $0.226 \%$ & $0.152 \%$ & $0.102 \%$ & $22.39 \%$ & $16.79 \%$ & $12.36 \%$ \\
\hline \multirow[t]{2}{*}{ host country } & 100 & $0.266 \%$ & $0.179 \%$ & $0.121 \%$ & $24.23 \%$ & $18.27 \%$ & $13.51 \%$ \\
\hline & $\begin{array}{c}\text { mean }-2 \mathrm{SD} \\
\text { mean }-1 \mathrm{SD} \\
\text { mean } \\
\text { mean }+1 \mathrm{SD} \\
\text { mean }+2 \mathrm{SD}\end{array}$ & $\begin{array}{l}0.072 \% \\
0.134 \% \\
0.246 \% \\
0.453 \% \\
\end{array}$ & $\begin{array}{l}0.049 \% \\
0.090 \% \\
0.166 \% \\
0.305 \% \\
\end{array}$ & $\begin{array}{l}0.033 \% \\
0.060 \% \\
0.112 \% \\
0.206 \% \\
\end{array}$ & $\begin{array}{l}17.44 \% \\
20.91 \% \\
24.85 \% \\
29.27 \% \\
34.11 \% \\
\end{array}$ & $\begin{array}{l}12.87 \% \\
15.60 \% \\
18.78 \% \\
22.44 \% \\
26.57 \% \\
\end{array}$ & $\begin{array}{c}9.36 \% \\
11.44 \% \\
13.91 \% \\
16.82 \% \\
20.19 \% \\
\end{array}$ \\
\hline Number of Prior & 1 & $0.237 \%$ & $0.159 \%$ & $0.107 \%$ & $21.43 \%$ & $15.53 \%$ & $11.14 \%$ \\
\hline Entries by Firms in the & 10 & $0.767 \%$ & $0.517 \%$ & $0.348 \%$ & $39.99 \%$ & $29.76 \%$ & $21.78 \%$ \\
\hline Same Industry & 50 & $1.878 \%$ & $1.270 \%$ & $0.857 \%$ & $61.35 \%$ & $47.64 \%$ & $36.14 \%$ \\
\hline \multirow{2}{*}{$\begin{array}{l}\text { into the prospective } \\
\text { host country }\end{array}$} & 100 & $2.788 \%$ & $1.890 \%$ & $1.278 \%$ & $72.13 \%$ & $57.40 \%$ & $44.52 \%$ \\
\hline & $\begin{array}{c}\text { mean }-2 \mathrm{SD} \\
\text { mean }-1 \mathrm{SD} \\
\text { mean } \\
\text { mean }+1 \mathrm{SD} \\
\text { mean }+2 \mathrm{SD}\end{array}$ & $\begin{array}{l}0.151 \% \\
0.267 \% \\
0.554 \% \\
1.161 \%\end{array}$ & $\begin{array}{l}0.102 \% \\
0.180 \% \\
0.373 \% \\
0.782 \%\end{array}$ & $\begin{array}{l}0.068 \% \\
0.121 \% \\
0.251 \% \\
0.527 \%\end{array}$ & $\begin{array}{l}24.65 \% \\
34.72 \% \\
49.70 \% \\
69.81 \% \\
92.56 \%\end{array}$ & $\begin{array}{l}18.02 \% \\
25.67 \% \\
37.55 \% \\
54.72 \% \\
76.16 \%\end{array}$ & $\begin{array}{l}13.02 \% \\
18.70 \% \\
27.82 \% \\
41.82 \% \\
60.94 \%\end{array}$ \\
\hline Subsidiary-Years of & 1 & $0.080 \%$ & $0.054 \%$ & $0.036 \%$ & $15.06 \%$ & $11.03 \%$ & $7.97 \%$ \\
\hline Firm International & 10 & $0.216 \%$ & $0.145 \%$ & $0.098 \%$ & $20.25 \%$ & $15.07 \%$ & $11.04 \%$ \\
\hline \multirow[t]{7}{*}{ Experience } & 50 & $0.431 \%$ & $0.290 \%$ & $0.195 \%$ & $24.60 \%$ & $18.57 \%$ & $13.75 \%$ \\
\hline & 100 & $0.581 \%$ & $0.391 \%$ & $0.264 \%$ & $26.66 \%$ & $20.27 \%$ & $15.09 \%$ \\
\hline & mean - 2SD & & & & $17.90 \%$ & $13.23 \%$ & $9.63 \%$ \\
\hline & mean - 1SD & $0.053 \%$ & $0.036 \%$ & $0.024 \%$ & $21.17 \%$ & $15.81 \%$ & $11.60 \%$ \\
\hline & mean & $0.134 \%$ & $0.090 \%$ & $0.060 \%$ & $24.85 \%$ & $18.78 \%$ & $13.91 \%$ \\
\hline & mean + 1SD & $0.334 \%$ & $0.225 \%$ & $0.151 \%$ & $28.93 \%$ & $22.16 \%$ & $16.60 \%$ \\
\hline & mean $+2 \mathrm{SD}$ & $0.833 \%$ & $0.562 \%$ & $0.378 \%$ & $33.39 \%$ & $25.95 \%$ & $19.68 \%$ \\
\hline Subsidiary-Years of & 1 & & & & $49.62 \%$ & $32.78 \%$ & $19.45 \%$ \\
\hline Firm Country-Specific & 10 & & & & $55.35 \%$ & $38.04 \%$ & $23.31 \%$ \\
\hline \multirow[t]{7}{*}{ Experience } & 50 & & & & $59.29 \%$ & $41.90 \%$ & $26.31 \%$ \\
\hline & 100 & & & & $60.95 \%$ & $43.59 \%$ & $27.68 \%$ \\
\hline & mean - 2SD & & & & $53.60 \%$ & $44.68 \%$ & $36.09 \%$ \\
\hline & mean - 1SD & & & & $56.10 \%$ & $47.19 \%$ & $38.45 \%$ \\
\hline & mean & & & & $58.57 \%$ & $49.71 \%$ & $40.86 \%$ \\
\hline & mean + 1SD & & & & $60.99 \%$ & $52.23 \%$ & $43.32 \%$ \\
\hline & mean $+2 \mathrm{SD}$ & & & & $63.37 \%$ & $54.74 \%$ & $45.81 \%$ \\
\hline
\end{tabular}

Note: Probabilities are computed using significant coefficient estimates from column 8 of Table 3 assuming a 1990 entry by a firm in the transportation sector into Asia holding all other independent variables constant at their mean levels for the relevant estimating sample. 
Table 6: Sensitivity of Predicted Probability of Plant Location in a Prospective Host Country

\begin{tabular}{|c|c|c|c|}
\hline $\begin{array}{l}\text { Variable Changed by } \\
\text { One Standard Deviation } \\
\text { from its Mean Level }\end{array}$ & $\begin{array}{c}\text { Without Firm-Specific } \\
\text { Experience (Firm- } \\
\text { Specific Uncertainty } \\
\text { High) }\end{array}$ & $\begin{array}{c}\text { With Firm-Specific } \\
\text { Experience (Firm- } \\
\text { Specific Uncertainty } \\
\text { Low) }\end{array}$ & $\begin{array}{c}\text { Ratio of High to Low } \\
\text { Firm-Specific } \\
\text { Uncertainty } \\
\text { (Column } 1 \text { to Column 2) }\end{array}$ \\
\hline Number of Prior Entries by Other Firms & $84 \%$ & $19 \%$ & $433 \%$ \\
\hline Number of Prior Entries by Firms in the Same In dustry & $130 \%$ & $46 \%$ & $235 \%$ \\
\hline Subsidiary-Years of Firm International Experience & $150 \%$ & $18 \%$ & $834 \%$ \\
\hline
\end{tabular}

Note: Probabilities are computed using significant coefficient estimates from column 8 of Table 3 assuming a 1990 entry by a firm in the transportation sector into Asia holding all other independent variables constant at their mean levels $f$ or the relevant estimating sample. 


\section{Appendix 1 \\ Deriving the Political Hazards Measure ${ }^{4}$}

This measure draws upon the theoretical foundations of work in positive political theory that employs spatial modeling frameworks to demonstrate that policy outcomes are a function of political structure. To construct a structurally-derived internationally comparable measure of political hazards, one must simplify the structure of political systems in a manner that allows for cross-national comparisons while retaining the elements of that structure that have strong bearings on the feasibility of policy change. The measure focuses on two such elements: the number of independent veto points over policy outcomes and the distribution of preferences of the political actors.

Assume, initially, that the status quo policy and the preferences of all actors with effective veto power (a subset of the executive, lower and upper legislative chambers, judiciary and state or provincial bodies) are independently and identically drawn from a uniformly distributed unidimensional policy space $[0,1]$. The variable of interest to investors in this model is the extent to which a given political actor is constrained in his or her choice of future policies. This variable is calculated as the expected range of policies for which a change in the status quo can be agreed upon by all political actors with veto power. For example, regardless of the status quo policy, an unchecked executive can always obtain their preferred policy. Investors face a high degree of uncertainty since the Executive's preferences may change or the Executive may be replaced by another executive with vastly different preferences. In this polar case, political hazards equal one.

\footnotetext{
${ }^{4}$ For more detail see Henisz (2000).
} 
As the number of actors with independent veto power increases, the level of political hazards decreases. For example, in a country with an effective unicameral legislature, the Executive must obtain the approval of a majority of the le gislature in order to implement policy changes. The Executive is no longer guaranteed their preferred policy as the legislature may veto a change from the status quo policy. The Executive can, at best, achieve the outcome closest to their preferred policy that is preferred by the legislature to the status quo.

Note that this initial calculation is based solely on the number of de jure veto points in a given polity maintaining the strong and unrealistic assumption of uniformly distributed preferences. However, neither the Constitutional existence of veto power nor its prior exercise provide a de facto veto threat in the current period. Specifically, alignment (i.e., majority control of the executive and the legislature by the same party) would be expected to increase the level of political hazards. To allow for this effect, the initial measure of political hazards described above is supplemented with information on the preferences of various actors. For example, if the legislature were completely aligned with the Executive, the game would revert back to our simple unitary actor discussed above with a hazards measure of one. The same exercise of determining hazards given the assumption of either completely independent or completely aligned actors was conducted for all observed political structures (every possible combination of executive, lower and upper legislative chambers, judiciary and state or provincial bodies).

Further modifications are required when other political actors are neither completely aligned with nor completely independent from the executive. In these cases, the party composition of the other branches of government are also relevant to the level of hazards. For example, if the party controlling the executive enjoys a majority in the legislature, the level of hazards is positively correlated with the magnitude and concentration of that majority. Aligned 
legislatures with large homogeneous majorities are less costly to manage and control than aligned legislatures with precarious majorities that are highly heterogeneous and/or polarized.

By contrast, when the executive is faced with an opposition legislature, the level of hazards is negatively correlated with the magnitude and concentration of the legislative majority. A heavily fractionalized opposition with a precarious majority imposes fewer constraints on the executive due to the difficulty in forming a cohesive legislative opposition bloc to any given policy. Information on the partisan alignment of different government branches and on the difficulty of forming a majority coalition within them can therefore provide valuable information as to the extent of political hazards.

Perspective can be gained by examining long-term time trends of these variables. From 1960 to 1998, the largest improvements in political hazards were recorded by countries undergoing democratic transitions in Latin America, Asia and Eastern Europe. Notable deteriorations in scores were recorded only by Burundi, Chile (under Pinochet), Guyana, Jamaica (1985-89), Lebanon, Nigeria, Panama, the Philippines (under Marcos), Sierra Leone, Sri Lanka, Somalia and Uruguay.

These scores align closely with our intuition as to the level of and change in political hazards in these countries. Furthermore, the measures are strongly correlated with the extant measures more commonly employed in the literature including the aggregate country risk index of The International Country Risk Guide (0.78) and the Polity executive constraint index (0.71). Interestingly, one of the regions where the correlation breaks down in an important way is South and East Asia which are scored quite highly (low country risk and strong constraints) by both ICRG and Polity but, due to the lack of formal veto points, strongly aligned and homogeneous 
legislatures and subservient court systems scored quite high on hazards. ${ }^{5}$ Events in the late 1990s in these countries lend credence to the values assigned by the methodology described in this appendix relative to extant measures.

The strong positive correlation of these three measures over the post-war period indicates that, despite their different methodologies, the three measures track the same underlying phenomenon: the quality of political institutions. However, the relative objectivity of the political hazards measure offers advantages to experience-based measures especially in times of rapid political change. Specifically, rather than wait for hopefully accurate improvements in the subjective perceptions of country risk (ICRG) or constraints on the executive (Polity), the methodology described in this appendix examines the structure of the political system and assesses the likelihood that future government policy will be constrained. Observation of the political transitions in Peru, the Philippines, South Africa and South Korea support this hypothesis as POLCON values shifted in the year of the transition in all cases while POLITY and ICRG scores shifted with a lag of up to five years or not at all.

5. The 1994 scores for Korea, Thailand, Malaysia and Indonesia were 7, 6, 6, 6 by ICRG (out of a maximum of 7 with a 1994 mean of 4.1); 7, 4, 7, and 2 by Polity (out of a maximum of 7 with a 1994 mean of 4.8); and $0.59,0.66,0.87$ and 1 on political hazards (out of a maximum of 1 with a 1994 mean of 0.65$)$. 


\section{REFERENCES}

Abrahamson, Eric and Lori Rosenkopf

1993 "Institutional and Competitive Bandwagons: Using mathematical modeling as a tool to explore innovation diffusion." Academy of Management Review, 18: 487-517.

Aharoni, Yair

1966 "The Foreign Investment Decision Process.": Graduate School of Business, Harvard University.

Allison, Paul D.

1984 Event History Analysis: Regression for Longitudinal Event Data. Beverly Hills, CA: Sage.

Anand, Jaideep and Bruce Kogut

1997 "Technological Capabilities of Countries, Firm Rivalry and Foreign Direct Investment." Journal of International Business Studies, 28: 445-465.

Argote, Linda, Sara L. Beckman, and Dennis Epple

1990 "The Persistence and Transfer of Learning in Industrial Settings." Management Science, 36: 140154.

Barkema, Harry G. , John H. J. Bell, and Johannes M. Pennings

1996 "Foreign entry, cultural barriers, and learning." Strategic Management Journal, 17: 151-166.

Belderbos, Rene and Leo Sleuwaegen

1996 "Japanese Firms and the Decision to Invest Abroad: Business Groups and Regional Core

Networks." Review of Economics and Statistics, 78: 214-220.

Billington, Nicholas

1999 "The Location of Foreign Direct Investment: An empirical analysis." Applied Economics, 31: 6576.

Blomstrom, Magnus

1991 "Host Country Benefits of Foreign Direct Investment." In D. G. McFetridge (ed.), Foreign investment, Technology and Economic Growth. Toronto: University of Toronto Press.

Burns, Lawton R. and Douglas R. Wholey

1993 "Adoption and Abandonment of Matrix Management Programs: Effects of Organizational Characteristics and Interorganizational Networks." Academy of Management Journal, 36: 106- 138.

Carroll, Glenn R., Jacques Delacroix, and Jerry Goldstein

1988 "The Political Environments of Organizations: An ecological view." Research in Organizational Behavior, 10: 359-392.

Caves, R.E.

1971 "International Corporations: The industrial economics of foreign investment." Economica, 38: 1-27.

Caves, Richard E.

1996 Multinational Enterprise and Economic Analysis, 2nd ed. Cambridge, MA: Cambridge University Press.

Chang, Sea Jin 
1995 "International expansion strategy of Japanese firms: Capability building through sequential entry." Academy of Management Journal, 38: 383-407.

Chang, Sea Jin and Philip M. Rosenzweig

2001 "The Choice of Entry Mode in Sequential Foreign Direct Investment." Strategic Management Journal, 22: 747-776.

Chung, Wilbur and Juan Alcacer

2000 "Heterogeneous Investment Motives and Location Choice of Foreign Direct Investment in the United States." Mimeo.

Chung, Wilbur, Will Mitchell, and Bernard Yeung

1998 "Foreign Direct Investment and Host Country Productivity: The American automotive component industry in the 1980s." University of Michigan Working Paper.

Cyert, Richard M. and James G. March

1963 A Behavioral Theory of the Firm, 2 ed. Cambridge, MA: Blackwell Business.

Darr, Eric D., Linda Argote, and Dennis Epple

1995 "The Acquisition, Transfer and Depreciation of Knowledge in Service Organizations: Productivity in franchises." Management Science, 41: 175-1762.

Davis, Gerald F.

1991 "Agents Without Principles? The spread of the poison pill through the intercorporate network." Administrative Science Quarterly, 36: 583-613.

Davis, Gerald F. and Henrich R. Greve

1997 "Corporate Elite Networks and Governance Changes in the 1980s." American Journal of Sociology, 103: 1-37.

Delacroix, Jacques and Anand Swaminathan

1991 "Cosmetic, Speculative and Adaptive Organizational Change in the Wine Industry: A longitudinal study." Administrative Science Quarterly, 36: 631-661.

Delios, Andrew and Witold J. Henisz

2000 "Japanese Firms' Investment Strategies in Emerging Economies." Academy of Management Journal, 43: 305-323.

DiMaggio, Paul J. and Walter W. Powell

1983 "The Iron Cage Revisited: Institutional Isomorphism and Collective Rationality in Organizational Fields." American Sociological Review, 48: 147-160.

Dodwell

1996/97 Industrial groupings in Japan: The anatomy of the keiretsu (12th ed. Tokyo, Japan: Dodwell Marketing Consultants.

Dunning, John H.

1993 Multinational Enterprises and the Global Economy. Don Mills, Ontario: Addison-Wesley.

Festinger, Leon

1954 "A Theory of Social Comparison Processes." Human Relations, 7: 117-140. 
Fligstein, Neal

1985 "The Spread of the Multidivisional Form Among Large Firms, 1919-1979." American Sociological Review, 50: 377-391.

Fombrun, Charles and Mark Shanley

1990 "What's in a name? Reputation building and corporate strategy." Academy of Management Journal, 33: 233-258.

Ford, Stuart and Roger Strange

1999 "Where do Japanese Manufacturing Firms Invest Within Europe and Why?" Transnational Corporations, 8: 117-142.

Gastanaga, Victor M., Jeffrey B. Nugent, and Bistra Pashamova

1998 "Host Country Reforms and FDI Inflows: How much difference do they make?" World

Development, 26: 1299-1314.

Geertz, Clifford

1978 "The Bazaar Economy: Information and search in peasant marketing." American Economic Review, 68: 28-32.

Gerlach, Michael L.

1992 "Alliance Capitalism: The Social Organization of Japanese Business.",: 351. Berkeley, CA: University of California Press.

Graham, Edward M.

1978 "Transatlantic Investment by Multinational firms: A rivalistic phenomenon?" Journal of PostKeynesian Economics, 1: 82-99.

Greene, William H.

1997 Econometric Analysis. Englewood Cliffs, NJ: Prentice Hall.

Greve, Henrich R.

1996 "Patterns of Competition: The diffusion of a market position in radio broadcasting." Administrative Science Quarterly, 41: 29-60.

2000 "Market Niche Entry Decisions: Competition, learning and strategy in Tokyo banking, 1894-1936." Academy of Management Journal, 43: 816-836.

Grubaugh, Stephen G.

1987 "Determinants of Foreign Direct Investment." Review of Economics and Statistics, 69: 149-152.

Guillén, Mauro

2001 "Structural Inertia, Imitation and Foreign Expansion: South Korean firms and business groups in China, 1987-1995." Academy of Management Journal, Forthcoming.

Haleblian, Jerayr and Sydney Finkelstein

1999 "The Influence of Organization Acquisition Experience on Acquisition Performance: A behavioral learning theory perspective." Administrative Science Quarterly, 44: 29-56.

Hammond, Thomas H. and Christopher K. Butler 
1996 "Some Complex Answers to the Simple Question, "Do Institutions Matter?": Aggregation rules, preference profiles, and policy equilibria in Presidential and Parliamentary systems." Political Institutions and Public Choice Working Paper (Michigan State University's Institute for Public Policy and Social Research), 96.

Hannan, Michael T. and Glenn R. Carroll

1992 The Dynamics of Organizational Populations. New York: Oxford University Press.

Hannan, Michael T., Glenn R. Carroll, Elizabeth A. Dundon, and John Charles Torres

1995 "Organizational Evolution in a Multinational Context: Entries of Automobile Manufacturers in Belgium, Britain, France, Germany, and Italy." American Sociological Review, 60: 509-528.

Haunschild, Pamela R.

1993 "Interorganizational Imitation: The impact of interlocks on corporate acquisition activity." Administrative Science Quarterly, 38: 564-592.

1994 "How Much Is That Company Worth? Interorganizational Relationships, Uncertainty and Acquisition Premiums." Administrative Science Quarterly, 39: 391-411.

Haunschild, Pamela R. and C.M. Beckman

1998 "When do Interlocks Matter? Alternate Sources of Information and Interlock Influence." Administrative Science Quarterly, 43: 815-844.

Haunschild, Pamela R. and Anne S. Miner

1997 "Models of Interorganizational Imitation: The effects of outcome salience and uncertainty."

Administrative Science Quarterly, 42: 472-500.

Haveman, Heather A.

1993a "Follow the Leader: Mimetic Isomorphism and Entry into New Markets." Administrative Science Quarterly, 38: 564-592.

1993 b "Organizational Size and Change: Diversification in the savings and loan industry after deregulation." Administrative Science Quarterly, 38: 20-50.

Haveman, Heather A. and Lynn Nonnemaker

2000 "Competition in Multiple Geographic Markets: The impact on growth and entry." Administrative Science Quarterly, 45: 232-267.

Haveman, Heather A. and Hayagreeva Rao

1997 "Structuring a Theory of Moral Sentiments: Institutional and Organizational Coevolution in the early thrift industry." American Journal of Sociology, 102: 1606-1651.

Helou, Angelina

1991 "The Nature and Competitiveness of Japan's Keiretsu." Journal of World Trade, 25: 99-131.

Henisz, Witold Jerzy

2000 "The Institutional Environment for Economic Growth." Economics and Politics, 12: 1-31.

Hennart, Jean-Francois and Young-Ryeol Park

1994 "Location, Governance and Strategic Determinants of Japanese Manufacturing Investment in the United States." Strategic Management Journal, 15: 419-436.

Horst, $\mathrm{T}$. 
1972 "Firm and Industry Determinants of the Decision to Invest Abroad: An empirical study." Review of Economics and Statistics, 54: 258-266.

Imai, Kenichi

1987 "The Corporate Network in Japan." Japanese Economic Studies, 16: 1-37.

Ingram, Paul and Joel Baum

1997 "Opportunity and Constraint: Organizations' learning from the operating and competitive experience of industries." Strategic Management Journal, 18: 75-98.

Kimura, Y.

1989 "Firm-Specific Strategic Advantages and Foreign Direct Investment Behavior of Firms: The Case of Japanese Semiconductor Firms." Journal of International Business Studies, 20: 296-314.

Kindleberger, C.P.

1983 "International Banks as Leaders or Followers of International Business." Journal of Banking and Finance, 7: 583-595.

Knickerbocker, F.T.

1973 Oligopolistic Reaction and the Multinational Enterprise. Cambridge, MA: Harvard University Press.

Kobrin, Stephen, John Basek, Stephen Blank, and Joseph La Palombara

1980 "The Assessment and Evaluation of Noneconomic Environments by American Firms: A preliminary report." Journal of International Business Studies, 11: 32-47.

Kobrin, Stephen J.

1985 "Diffusion as an Explanation of Oil Nationalization (Or the domino effect rides again)." Journal of Conflict Resolution, 29: 3-32.

Kogut, Bruce

1983 "Foreign direct investment as a sequential process." In C. P. Kindleberger (ed.), The Multinational Corporations In the 1980s: 35-56. Cambridge: MIT Press.

Kostova, Tatiana and Srilata Zaheer

1999 "Organizational Legitimacy Under Conditions of Complexity." Academy of Management Review, 24: 64-81.

Levitt, Barbara and James G. March

1988 "Organizational Learning." In W. R. Scott and J. Blake (eds.), Annual Review of Sociology.

Levy, Brian and Pablo T. Spiller

1994 "The Institutional Foundations of Regulatory Commitment: A Comparative Analysis of

Telecommunications Regulation." Journal of Law, Economics and Organization, 10: 201-246.

Li, Jiatao and Stephen Guisinger

1992 "The Globalization of Service Multinationals in the 'triad' nations: Japan, Europe and North America." Journal of International Business Studies, 23: 675-696.

Lincoln, James, Michael Gerlach, and Christine Ahmadjian

1992 "Evolving Patterns of Keiretsu Organization and Action in Japan." Research in Organizational Behavior, 20: 303-345. 
March, James

1988 Decisions in Organizations. New York: Blackwell.

Markusen, James R. and Keith E. Maskus

1999 "Discriminating Among Alternative Theories of the Multinational Enterprise." NBER Working Paper, 7164.

Marsden, Peter V. and Noah E. Friedkin

1993 "Network Studies of Social Influence." Sociologic al Methods and Research, 22: 127-151.

Martin, Xavier, Will Mitchell, and Anand Swaminathan

1995 "Recreating and Extending Japanese Automobile Buyer-Supplier Links in North America."

Strategic Management Journal, 16: 589-619.

Martin, Xavier, Anand Swaminathan, and Will Mitchell

1998 "Organizational Evolution in the Interorganizational Environment: Incentives and Constraints on International Expansion Strategy." Administrative Science Quarterly, 43: 566-601.

Mayer, T. and J-L Muchielli

1998 "Strategic Location Behavior: The case of Japanese investments in Europe." Journal of Transnational Management, 3: 131-167.

McFadden, Daniel S.

1974 "Conditional Logit Analysis of Qualitative Choice Behavior." In P. Zarembka (ed.), Frontiers in Econometrics: 105-142. New York: Academic Press.

Meyer, John and Brian Rowan

1977 "Institutionalized Organizations: Formal structures as myth and ceremony." American Journal of Sociology, 83: 340-363.

Meyer, John and W. Richard Scott

1983 "Organizational Environments: Ritual and Rationality." Beverly Hills, CA: Sage.

Mezias, Stephen J.

1990 "An Institutional Model of Organizational Practice: Financial reporting at the Fortune 200."

Administrative Science Quarterly, 35: 431-457.

North, Douglas

1990 Institutions, Institutional Change, and Economic Performance. New York: Cambridge University Press.

Oliver, Christine

1988 "The Collective Strategy Framework: An application to competing predictions of isomorphism." Administrative Science Quarterly, 33: 541-561.

Owen, R.F.

1982 "Inter-industry Determinants of Foreign Direct Investment." In A. Rugman (ed.), New Theories of Multinational Enterprise. London: Croom Helm.

Palmer, Donald A., P. Devereaux Jennings, and Xueguang Zhou 
1993 "Late Adoption of the Multidivisional Form by Large U.S. Corporations: Institutional, political and economic accounts." Administrative Science Quarterly, 38: 100-131.

Palmer, Donald, Roger Friedland, P. Devereaux Hennings, and Melanie E. Powers

1987 "The Economics and Politics of Structure: The multidivisional form and the large U.S. corporation." Administrative Science Quarterly, 32: 25-48.

Pennings, Johannes M. and Farid Harianto

1992 "The Diffusion of Technological Innovation in the Commercial Banking Industry." Strategic

Management Journal, 13: 29-46.

Pfeffer, Jeffrey and Gerald R. Salancik

1978 The External Control of Organizations. New York: Harper and Row.

Pindyck, Robert S. and Andres Solimano

1993 "Economic Instability and Aggregate Investment." NBER Macroeconomics Annual: 259-303.

Podolny, Joel M.

1994 "Market uncertainty and the social character of economic exchange." Administrative Science

Quarterly, 39: 458-483.

Powell, Walter W., Kenneth W. Koput, and Laurel Smith-Doer

1997 "Interorganizational Collaboration and the Locus of Innovation: Networks of learning in

biotechnology." Administrative Science Quarterly, 41: 116-145.

Root, Franklin R.

1968 "Attitudes of American Executives Towards Foreign Governments and Investment Opportunities." Economics and Business Bulletin: 14-23.

Strang, David

1991 "Adding Social Structure to Diffusion Models: An event history framework." Sociological Methods and Research, 19: 324-353.

Strang, David and Nancy B. Tuma

1993 "Spatial and Temporal Heterogeneity in Diffusion." American Journal of Sociology, 99: 614-639.

Thompson, James D.

1967 Organizations in Action: Social Science Bases of Administrative Theory. New York: McGraw-Hill Book Company.

Tolbert, Pamela S. and Lynne G. Zucker

1983 "Institutional Sources of Change in the Formal Structure of Organizations: The diffusion of civil service reform, 1880-1935." Administrative Science Quarterly, 28: 22-39.

Toyo Keizai

1999 Kaigai Shinshutsu Kigyou Sourankuni Betsu - Japanese Overseas Investments by Country. Tokyo: Toyo Keizai.

Tsebelis, George

2000 "Veto Players and Institutional Analysis." Governance, 13: 441-474.

Tushman, Michael L. and David A. Nadler 
1978 "Information Processes as an Integrating Concept in Organizational Design." Academy of Management Review, 3: 613-624.

United Nations

1997 World Investment Report 1997: United Nations.

Van De Vliert, Evert and Nico W. Van Yperen

1996 "Why Cross-National Differences in Role Overload? Don't Overlook Ambient Temperature!"

Academy of Management Journal, 39: 986-1004.

Wei, Shang-Jin

2000 "How Taxing is Corruption on International Investors." Review of Economics and Statistics, 82: 111.

Weingast, Barry

1993 "Constitutions as Governance Structures: The Political Foundations of Secure Markets." Journal of Institutional and Theoretical Economics, 149: 286-311.

Weinstein, D. E. and Y. Yafeh

1995 "Japan's corporate groups: Collusive or competitive? An empirical investigation of keiretsu behavior." Journal of Industrial Economics, 43: 359-376.

Westphal, James D., Ranjay Gulati, and Stephen M. Shortell

1997 "Customization or Conformity: An institutional and network perspective on the content and consequences of TQM adoption." Administrative Science Quarterly, 42: 366-394.

Wheeler, David and Ashoka Mody

1992 "International Investment Location Decisions: The case of U.S. firms." Journal of International Economics, 33: 57-76.

Williamson, Oliver E.

1996 The Mechanisms of Governance. New York: Oxford University Press.

Zucker, Lynne G.

1977 "The Role of Institutionalization in Cultural Persistence." American Sociological Review, 42: 726743.

Zukin, Sharon and Paul Dimaggio

1990 "Structures of Capital: The Social Organization of the Economy." Cambridge, MA: Cambridge University Press. 